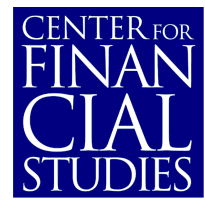

No. $2003 / 27$

\title{
German banks - a declining industry?
}

\author{
Andreas Hackethal
}

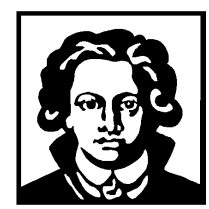




\title{
German banks - a declining industry?
}

\author{
Andreas Hackethal *
}

First Version: October 2002

This version: March 2003

\begin{abstract}
:
This paper is a draft for the chapter "German banks and banking structure" of the forthcoming book "The German financial system" edited by J.P. Krahnen and R.H. Schmidt (Oxford University Press). As such, the paper starts out with a description of past and present structural features of the German banking industry. Given the presented empirical evidence it then argues that great care has to be taken when generalising structural trends from one financial system to another. Whilst conventional commercial banking is clearly in decline in the US, it is far from clear whether the dominance of banks in the German financial system has been significantly eroded over the last decades. We interpret the immense stability in intermediation ratios and financing patterns of firms between 1970 and 2000 as strong evidence for our view that the way in which and the extent to which German banks fulfil the central functions for the financial system are still consistent with the overall logic of the German financial system. In spite of the current dire business environment for financial intermediaries we do not expect the German financial system and its banking industry as an integral part of this system to converge to the institutional arrangements typical for a market-oriented financial system.
\end{abstract}

JEL Classification: G21, G23

Keywords: Commercial banking, Germany, disintermediation, financial system

\footnotetext{
* Correspondence should be addressed to Andreas Hackethal, Wilhelm Merton Professur, Mertonstr. 17, 60325

Frankfurt am Main, Germany. E-mail: Hackethal@em.uni-frankfurt.de

I am grateful to Jean Dermine, Harry Schmidt, Jan Pieter Krahnen and Karl-Herrmann Fischer for very helpful comments and suggestions.
} 


\section{Introduction - Bank Disintermediation in Germany?}

In a recent speech, Bernd Fahrholz, the former CEO of Germany's third largest bank, acknowledged that ten years ago the German banking market was still a cozy place and that, at that time, hardly anybody would have imagined that any disruptions could occur at all (Fahrholz 2001). He then went on to characterize the structures that had prevailed for most of the post-World-War-II era. The German financial system was one of many neatly delineated systems in Europe with its own currency and a banking sector that did not have to fear foreign competition. In Germany things were especially orderly, most banks were organized as universal banks and acted as Hausbanks to their customers. ${ }^{1}$ Customers visited their local branch between 9am and 4pm to deposit their surplus funds almost exclusively into savings accounts, and firms funded their investments primarily with bank loans. The public banking sector did business as usual and nobody disapproved of its state guarantees. According to Fahrholz, since then "no stone has been left unturned". Ever more efficient capital markets and specialized non-bank financial institutions have allegedly eroded the once strong role of traditional universal banks. Apparently, German banks are suffering the same fate as their peers around the world. This view is also held by many international commentators 2 , among them Jeremy Edwards (1996, p.41): "Fundamental forces not limited to the United States have caused a decline in the profitability of traditional banking throughout the world and have created an incentive for banks to expand into new activities and to take greater risks ... The decline of traditional banking is a global phenomenon."

The sheer number of advocates subscribing to this view, as well as the firm conviction with which it is typically expressed, indicate that the banking industry is commonly believed to be in a process of profound structural change. As a consequence, universal banking and

1 The relationship between a firm and its Hausbank is typically more information-intensive and longer-term oriented and thus closer than any other of the firm's bank relationships. In the case of smaller firms, the Hausbank typically acts as the premier lender with a "special responsibility", whereas in the case of larger corporations, the Hausbank - in addition to its role as an important lender - holds direct shareholdings in the company and is represented on the company's supervisory board. Universal banks are commonly defined as banks that are active in both commercial banking and security underwriting and that hold equity stakes in their debtor firms. This organizational form of a bank is hence not only conducive but almost a precondition for achieving Hausbank status for larger firms.

2 See, for example Boyd/Gertler (1993, 1995), Becketti/Morris (1992), Calomiris (1997), Edwards/Mishkin (1995), Gorton/Rosen (1995), Greenbaum/Thakor (1995), Litan/Rauch (1998) and Miller (1998). See also the collection of interviews with chief officers from the banking industry in Engler/Essinger (2000). For an opposing view, see for example Dermine (2002), who uses the ratio of total bank assets over GDP to measure the importance of banks. He finds that this ratio more than doubled in most European countries between 1981 and 2000 and argues that this expansion must have been due to the massive deregulation that took place in Europe during this period (for related evidence see footnote 21). 
traditional commercial banking in particular, are supposedly in decline worldwide. There also seems to be a consensus on the reasons for this development. Firstly, progress in communication and information technology combined with innovative financial instruments are believed to foster the efficiency of organized capital markets. Relevant information can be made available to all participants almost instantaneously and the participants' capacity to process this information has increased dramatically. In addition, new instruments allow for better customization to accommodate the specific needs of the participants. Because many services offered by commercial banks on the one hand and capital markets on the other can be regarded as substitutes, any efficiency gains realized by the markets could clearly be detrimental to the role of banks and would thus erode their "uniqueness" 3 and, in turn, their share in the markets for financial services. Secondly, abandoning regulations that have historically shielded the banking industry from competition from nonbank financial intermediaries (NBFIs) and organized capital markets is regarded as fuelling this substitution process. This factor is assumed to be particularly strong in those cases in which the historically strong position of banks in a particular financial system may not have been based on their uniqueness, but rather on the regulatory protection that they have enjoyed. Thirdly, the trend towards globalization and, in the case of Europe, the monetary unification, is believed to intensify both forces - advances in technology and deregulation - as specialized nonbank financial intermediaries, e.g. large credit card companies or reputable investment banks that are highly successful in their domestic financial system, seek to expand rapidly around the globe.

This paper examines the current state and structure of the German banking market and its role within the German financial system. It thereby aims to answer the question whether the fundamental forces cited above have indeed dismantled the alleged uniqueness of German

3 James (1987) showed in his article "Some Evidence on the Uniqueness of Bank Loans" that the announcement by an American corporation to take out a bank loan typically leads to an increase in the firm's market value. Based on the observation that entering a relationship with a bank creates value, James concludes that banks are unique with respect to the fulfilment of specific financial functions. For the sake of brevity we mention only some of the more recent contributions that investigate the uniqueness of the institution "bank" (see Greenbaum/Thakor (1995) and Freixas/Rochet (1997) for two brilliant surveys on recent advances in the theory of financial intermediation). Because individual liquidity insurance à la Diamond/Dybvig (1983) is also being provided to some extent by money market mutual funds (see Rajan (1996) for a discussion) and because thorough monitoring à la Diamond (1994) is also being conducted by finance and insurance companies, the uniqueness of banks must stem from the combination of these two functions under the roof of a single institution. Scope economies may result a) from a more efficient use of liquidity reserves (Kashyap/Rajan/Stein 1999), b) from a broader information base on debtors (Fama (1985); Lewis (1991)), c) from reduced incentive problems regarding the investment of deposited funds (Myers/Rajan 1998), and d) from the improved ability to absorb systemic shocks (Allen/Gale 1997). 
universal banks leading to similar developments and whether they will share the fate of their European and American peers leading to a structural convergence of national banking markets. In such a possible future scenario, banks are no longer clear substitutes for organized capital markets but rather important complementary institutions. Instead of providing their customers with access to their own balance sheets, they will assist them in accessing increasingly complex capital markets and moving undesired risks off their balance sheet by means of financial innovations.

The next section describes the key characteristics of the major German banking groups. Section 3 analyses structural features and performance indicators of the German banking industry and compares them to those in other European countries and in the United States. It will become apparent that some trends like that of a declining number of banks, decreasing interest margins, and the increasing importance of fee-based business are discernible in all countries. However, this does not seem to be the entire story. In section 4 we provide additional indicators which attempt to capture the role of the banks in several financial systems, and in Germany in particular. This evidence reveals that the simplistic convergence hypothesis might indeed be false. German commercial banks and especially savings and cooperative banks still seem to play a special role. Sections 5 and 6 conclude by discussing the outlook for private and public banks and by summarizing the main findings.

\section{The structure of the banking market}

\subsection{Banking groups - an overview}

The German banking system is a universal banking system. Banks have been permitted to engage in all lines of banking businesses for a very long time and the few existing special banks have not emerged as a result of legal regulations. Rather, the laws governing these special banks have developed in response to their emergence and the perceived necessity to apply special regulations. Figure 1 shows that out of the roughly 3,000 monetary financial institutions that existed at the end of 2000 2,713 were universal banks and 218 were special 
institutions, including 141 entities that in our context should actually be classified as nonbank financial institutions (e.g. investment companies). ${ }^{4}$

About $20 \%$ of all German banks belong to the public savings group and about $60 \%$ belong to the co-operative banking sector. Hence, more than $80 \%$ of all German banks are not strictly profit maximizing entities. Figure 2 below shows the size distribution of the banks from the four main bank groups. It reveals that most co-operative banks are indeed very small institutions. The majority had assets of less than 500 million Euro in 2000. In contrast, most savings banks and all Land banks had assets above this value. The private commercial banking group is quite heterogeneous with respect to size. Small private bankers as well as Germany's four largest banks belong to this group. Most special banks are among the largest German banks with total assets in excess of 5 billion Euro.

Figure 1: German banking groups and number of banks at the end of 2000

\begin{tabular}{|c|c|c|c|c|c|c|c|c|c|c|c|c|c|}
\hline \multicolumn{14}{|c|}{ Monetary Financial Institutions (2931) } \\
\hline & \multicolumn{7}{|c|}{ Universal banks (2713) } & \multicolumn{6}{|c|}{ Special Institutions (218) } \\
\hline & \multicolumn{3}{|c|}{$\begin{array}{c}\text { Commercial Banks } \\
(354)\end{array}$} & \multicolumn{2}{|c|}{\begin{tabular}{|c|} 
Credit Co-operatives \\
$(1798)$ \\
\end{tabular}} & \multicolumn{2}{|c|}{$\begin{array}{c}\text { Savings Banks } \\
(561) \\
\end{array}$} & \multicolumn{3}{|c|}{$\begin{array}{c}\text { Special Banks } \\
(77)\end{array}$} & \multicolumn{3}{|c|}{$\begin{array}{c}\text { Other MFIs } \\
(141)\end{array}$} \\
\hline 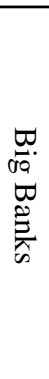 & 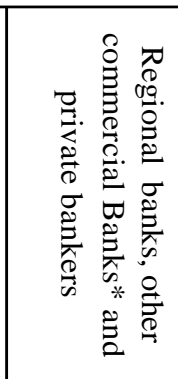 & 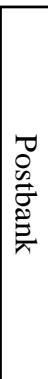 & 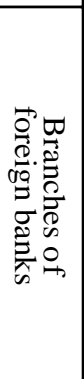 & 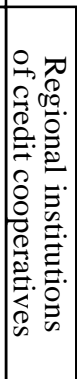 & 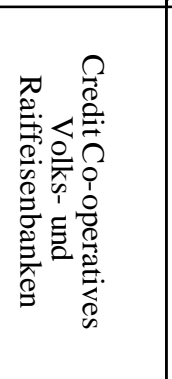 & 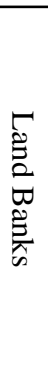 & 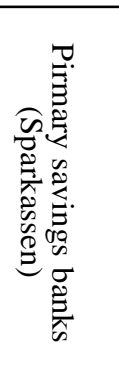 & 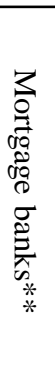 & 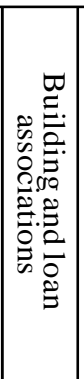 & 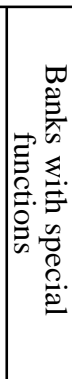 & 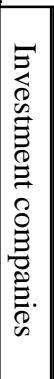 & 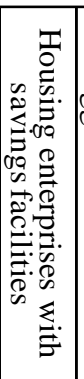 & 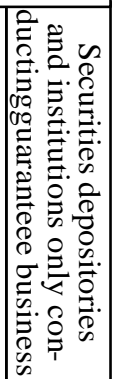 \\
\hline
\end{tabular}

Number of instituions (private ownership (2355)/public ownership (576))

* Included are banks majority-owned by foreign financial and non-financial companies.

Figure 2: Size distribution of banks from different groups (12/2000)

4 The German Banking Act defines banks very broadly. Monetary financial institutions (banks) comprise (1) credit institutions, which conduct any of the following: deposit business, lending business, discount business, principal broking services, safe custody business, investment fund business, guarantee business, giro business, underwriting business, prepaid card business, network money business; and (2) financial services institutions that engage in either investment broking, contract broking, portfolio management, own-account trading, non-EEA deposit broking, money transmission services or foreign currency dealing. 


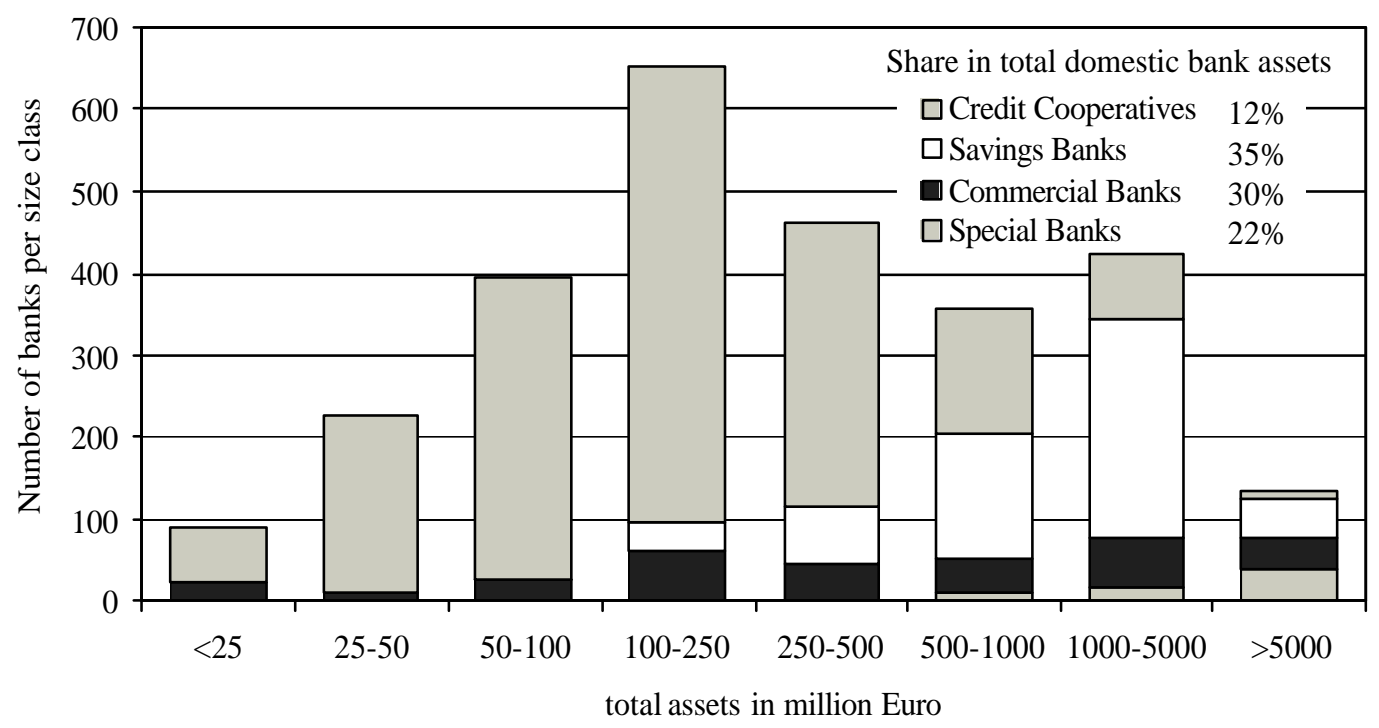

Source: Deutsche Bundesbank (2001)

Table A1 in the appendix lists Germany's largest 30 banks by name, total domestic and international group assets, number of branches and employees and by bank group. These 30 banks amount to roughly $50 \%$ of all German bank assets. ${ }^{5}$ This includes the four big private sector banks, which cover $16 \%$ of German bank assets, ten of the thirteen public Land banks (19\%) and all three regional institutions of credit co-operatives (4\%). It is interesting to note that only 13 of the 30 largest banks in Germany were strictly profit-maximizing entities.

Because the combined market share in total domestic bank assets of the top five banks is lower than $20 \%$, the German banking system is often viewed as being very fragmented. As will be argued below, the savings bank group and the co-operative group might well be treated as if each were a single large entity. In this case, the top-5 market share jumps up to $59 \%$, which is close to the European average value of 57\% in 1999 (ECB 2000). We will now describe the four main banking groups in more detail.

\subsection{Commercial Banks}

The first German joint-stock banks were established in the middle of the $19^{\text {th }}$ century. At this time, private bankers were no longer able to satisfy the growing financing needs of massproduction industrial companies. A consolidation wave fuelled by the banking crisis of

5 The data in the top-30 list of the Association of German banks cannot not be directly compared to the data of the Deutsche Bundesbank, which we refer to in most other tables and figures of this paper. Whilst the former are based on the consolidated annual reports of banks, the Bundesbank data are based on monthly balance sheet statistics that cover only those parts of German banks which are located in Germany, ie. their headquarters and their domestic branches. Moreover, the top-30 list includes some double counting as the largest private mortgage banks appear on the list as part of Deutsche-, Dresdner- and Commerzbank, respectively, as well as in their own right. 
1931/1932 led to the emergence of three dominant players, namely Dresdner Bank (founded in 1872), Deutsche Bank (1870) and Commerzbank (1870). After having been disbanded in the wake of World War II, all three reassembled between 1957 and 1958. Today, they still act as the Hausbanks to Germany's large industrial corporations and form the core of Germany's private commercial banking group. The Bayerische Hypo- und Vereinsbank (HVB), which resulted from a 1998-merger between two large Bavarian banks, joined the Deutsche Bundesbank category of big banks in 1999. Its retail business was traditionally located in the southern parts of Germany but has been expanded to the rest of Germany, Austria and Central and Eastern Europe during the recent past.

All four big banks are truly universal banks in that their retail and corporate banking businesses are complemented by growing investment banking activities. Deutsche Bank, which acquired the British investment bank Morgan Grenfell in 1989 and the US institution Bankers Trust in 1997, and Dresdner Bank, which followed suit by acquiring Kleinwort Benson in 1995 have been aggressively expanding their investment banking arms. In 1999, Deutsche ranked first, Dresdner second and Commerzbank fourth among large European universal banks in terms of the portion of total capital that was allocated to wholesale and investment banking. 6 Moreover, the big banks' fully- or majority-owned mortgage banks 7 , their building and loan associations and their investment companies are among the largest in the German market. Their current bancassurance strategies, however, differ considerably. Whereas Deutsche Bank sold its insurance arm in 2001, Dresdner itself was bought by Allianz, Germany's largest insurance group, in the same year. Commerzbank is cooperating with Generali, Italy's largest insurance group, and HVB is cooperating with ERGO, Germany's second largest insurance company owned by Munich Re.

Although all four banks belong to the largest institutions in the world, their combined market share in deposits from German non-banks was lower than 14\% at the end of 2000. They operate 2,873 branches compared to the 16,892 branches of the savings bank group and the 15,332 branches of the co-operative banking group. As a consequence of this discrepancy,

\footnotetext{
6 In a joint study, Goldman Sachs and McKinsey estimate that German banks captured $23 \%$ of total revenues in the European corporate banking market in 1999. However, British banks were still far ahead with a combined market share of $39 \%$ (Leadem et al 2001).

7 Because of its status as a hybrid mortgage bank, HVB is the only German big bank that is exempted from the provision of the German mortgage act from 1899, which prohibits commercial banks from conducting mortgage banking business on their own behalf.
} 
the four big banks cooperate with regards to ATM usage; customers of one big bank can withdraw cash from an ATM of another big bank free of charge.

Regional and other commercial banks comprise of all German private $2^{\text {nd }}$ and $3^{\text {rd }}$ tier banks. The largest are Bankgesellschaft Berlin (rank 10 in 2000) ${ }^{8}$, Postbank (rank 22), which is fully owned by the privatized German postal service, BHF-Bank (rank 27), which has been acquired by the Dutch ING Group in 1999, Deutsche Bank 24 (rank 31), which comprises the retail banking activities of Deutsche Bank Group, SEB (rank 34) which is fully owned by the Swedish Skandinaviska Enskilda Banken, Baden Württembergische Bank (rank 46), Deutsche Kreditbank (rank 51), Vereins- und Westbank (rank 52), Volkswagenbank, (rank 66), and Citibank Privatkunden (rank 73). With the exception of some $2^{\text {nd }}$ tier banks such asBHFBank, SEB and Citibank and the direct banks and brokerages like Volkswagenbank, Allgemeine Deutsche Direktbank (rank 96), Consors, and Comdirect most banks in this category focus on their regional retail or wholesale market.

Included in the group of commercial banks are also the private bankers. Some of them like Joh. Berenberg, Gossler\& Co (founded in 1590 in Hamburg), B. Metzler Seel. Sohn\&Co. KGaA (founded in Frankfurt in 1674) and Delbrück\&Co. (founded in Cologne in 1712) are among the oldest banks still operating in Germany. Typically, they are controlled by ownermanagers who are personally liable for the financial obligations of their banks. Their number has been declining; it went from 1,406 institutions in 1925 to 491 in 1938 to only 50 at the end of 1998. Today their share in total assets of German bank's domestic operations is far below $1 \%$.

Roughly $2 \%$ of the same asset base were under the control of the 90 (up from 63 in 1985) German branches of foreign banks that existed at the end of 2000. Adding up the assets of those 56 commercial and mortgage banks that were majority-owned by foreign banks among them SEB and Citibank Privatkunden - yields the total share of German bank assets controlled by foreign banks or non-banks. This number was $8 \%$ in 2000 and has remained fairly stable during the last 15 years.

Figure 3: Balance sheet and income statement of commercial banks (1971-2000)

\footnotetext{
8 Bankgesellschaft Berlin, a quoted holding company majority owned by the state of Berlin, was created from the merger of Landesbank Berlin and two commercial banks, Berliner Bank and Berlin Hyp in 1994. It represents the only case to date in Germany of a cross-sector consolidation. It continues to be the case that a private-sector bank cannot acquire a public-sector bank.
} 

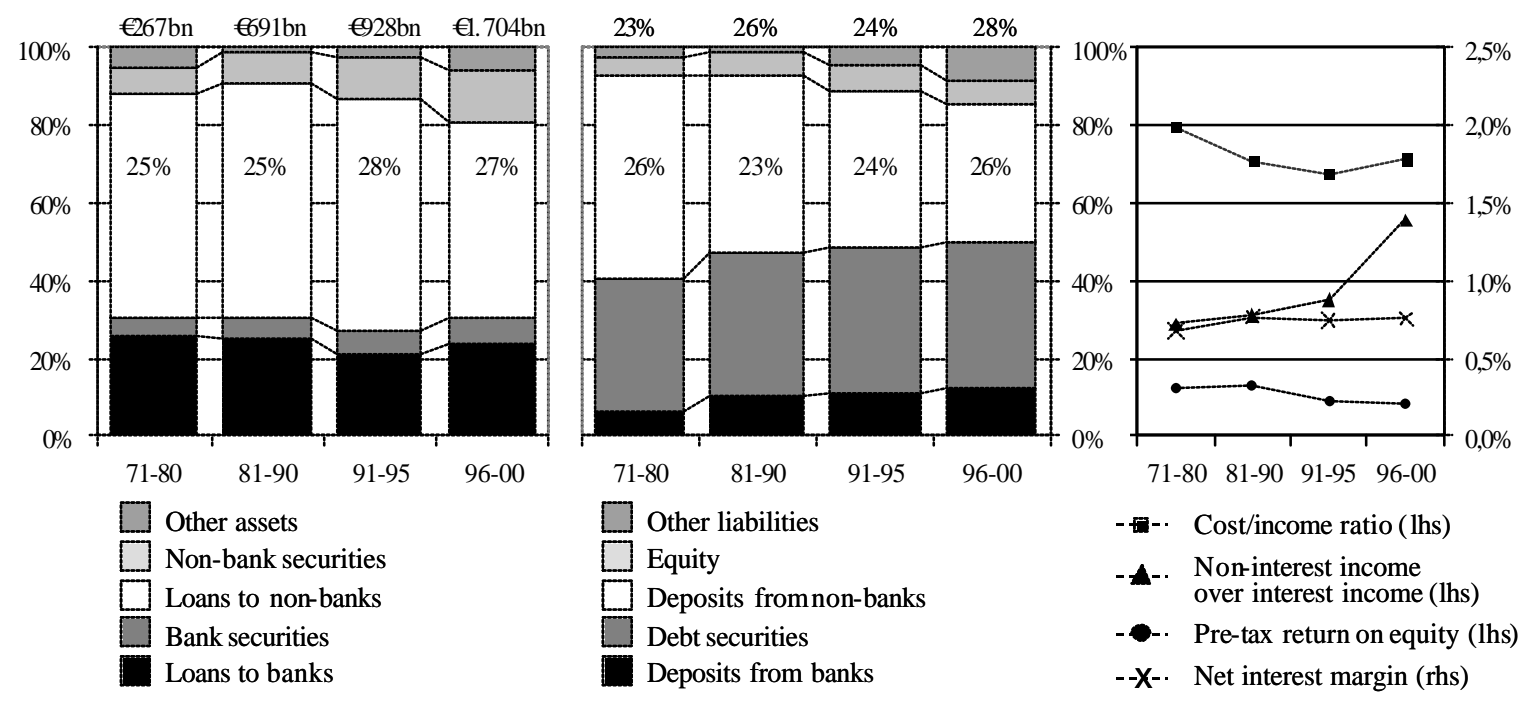

Note: Figures above asset-side columns show total domestic assets of all banks in the group at the end of 1980, 1990, 1995 and 2000. Percentage values indicate 5-year average market shares regarding total assets, loans to non-banks and deposits from non-banks.

Source: Deutsche Bundesbank (1998, 2000, 2001, 2001a)

Figure 3 above depicts the aggregated balance sheet and three key performance indicators for German private commercial banks. Loans to non-banks as a portion of total assets have declined from roughly $60 \%$ in the 70 s, 80 s and early 90 s to $50 \%$ during the late 90 s and have plummeted to $44 \%$ in 2000 . The portion of securities from non-banks, however, has increased from $7 \%$ in 1971 to almost $15 \%$ in 2000, indicating an increase in the importance of operations in close proximity to capital markets. The liability structure of commercial banks has changed even more dramatically. Although the banks in the group have managed to retain a market share of roughly $25 \%$ over the last 30 years, the share of deposits from non-banks in total liabilities has dropped from over $52 \%$ in the 70 s to $36 \%$ in the late 90 s and was under $35 \%$ in 2000. Deposits from banks and bank debentures now account for more than $50 \%$ of total liabilities.

In line with these balance sheet developments, the ratio of non-interest income to interest income has increased steadily over the last thirty years and reached an all-time-high of $86 \%$ in 2000 (59\% in 1999). During the same period the interest margin, defined as net interest revenue over total assets, has remained low at around $0.7 \%$. Pretax returns on equity have declined and reached an all-time-low of $6.6 \%$ in 2000 (7.8\% in 1999). Partly because of the income squeeze, the cost-income ratio exceeded $75 \%$ in 1999 and 2000 after commercial banks had managed to keep it below $70 \%$ for most of the last decade. 


\subsection{The savings bank group}

The first German public savings bank was founded in 1801 in Göttingen after most existing private savings banks had suffered seriously from the Napoleonic wars. The Prussian savings bank act of 1838 ruled out the legal independency of all 234 Prussian savings banks and put them under the regime of the respective local governments. As a result of similar developments in all other German regions a total of 2,700 public institutions existed at the beginning of the $20^{\text {th }}$ century. To avoid an excessive indebtedness of local governments in the wake of the great depression of 1929, savings banks were given autonomous legal status in 1931. Concurrently, the so called "Gewährträgerhaftung" (guarantee obligation) was introduced, which makes the public founding entity liable without restriction in the event of default by their savings bank and hence serves as a guarantee for third party lenders. In addition, the so called "Anstaltslast" (maintenance obligation) has since then placed with the founding entity the responsibility for ensuring that its savings bank is able to meet its financial obligations at all times, i.e. providing a capital injection or liquidity support when the bank is threatened by insolvency. Because the maintenance obligation by itself virtually rules out a default of the savings bank, the guarantee obligation has been put into force in only a very few cases (Helaba 1974-1976). Primarily owing to the constrained budgets of local governments and the avoidance of negative reputation effects, the maintenance obligation has also not been enforced very often. Mergers between banks susceptible to insolvency and healthy institutions have been preferred to bailouts.

Public savings banks are governed by the savings bank laws of the respective German states. These laws oblige the savings banks to serve the public interests of their region by fostering individual savings and by satisfying the credit needs of their local communities. They should thereby focus on the needs of employees, small and medium-sized enterprises which are commonly referred to as the German Mittelstand - and their public authority. For example, public savings banks are obliged to open a transaction account for every applicant. Typically, the laws further require that although savings banks have to conduct their businesses according to sound economic principles, profit maximization must not be their primary business objective. ${ }^{9}$ It also implies that the primary savings banks may typically not or only to a specified degree hold shares in enterprises outside the savings bank group, trade money market, equity or foreign exchange instruments on their own account or take part in an

\footnotetext{
9 See for example section 3 (3) of the savings bank law of the State of Northrhine-Westfalia.
} 
underwriting consortium. Moreover, to avoid competition between local savings banks, each institution is prohibited from operating outside its local area and encroaching upon its neighbors' territories ${ }^{10}$. In rural areas they typically compete with smaller co-operative banks, whereas in metropolitan areas they typically compete with the branches of the large private commercial banks.

Their governance structures are quite similar to those of private commercial banks. The executive board reports to a supervisory board called the "Verwaltungsrat". Two thirds of the seats of the supervisory board are typically determined by the founding entity as the owner of the bank, one third is elected by the employees. A third body, the credit committee, consists of at least three members of the supervisory board and gives the founding entity the opportunity to exert influence on important credit decisions.

In addition to the 541 public savings banks there exist seven free savings banks, which are essentially self-controlled and thus do not benefit from state guarantees but are otherwise more or less comparable to their public peers. One of them and at the same time the largest savings bank in Germany, the Hamburger Sparkasse (Haspa) acknowledged in its annual report for the year 2000 (p. 3) that it "[...]is unreservedly committed to the smaller business. The need to introduce an internal rating system (Basle II) will inevitably mean that lending terms will be tightened up to give more protection against lending risks. The smaller businesses will still get loans on attractive terms." This statement is accompanied by the following: "The profits we earn are ploughed back into Haspa. This sound footing has enabled us to adapt successfully to social and economic change throughout our 174-year history and to become a leading all-round financial institution for the local economic region". This form of profit appropriation is indeed typical for most savings banks. According to Sinn (1996) the ratio of retained earnings to net income has on average been $50 \%$ higher for savings banks than for private commercial banks in the period from 1980 to 1994. One obvious reason is of course that unlike their private competitors, public banks cannot raise external equity from third parties. Yet critics often argue that the practice by founding entities of tolerating such low pay-out ratios in addition to the guarantees provided by the public owners via the maintenance and guarantee obligations unduly insulates public banks from the pressure typically exerted by private shareholders and thereby renders competitive advantages to the savings bank group as a whole and to the Land banks in particular. As a consequence, the

10 Only when requested by a customer or after agreement by both the savings bank concerned and the 
group members would appear to be in a position to offer financial products to customers under favorable conditions which can hardly be matched by German and foreign private sector banks without squeezing margins to unattractive levels. ${ }^{11}$

Land banks and regional savings associations constitute the second tier of the savings bank group. The twelve Land banks have two primary functions. Firstly, they serve as the Hausbank to their state(s) and as such provide cash management services and grant loans, which are mainly refinanced by means of public "Pfandbriefe"12 (mortgage bonds) and public sector bonds. Secondly, they act as the central bank to the primary savings banks in their region and as such act as the clearing institution for inter-bank transfers and support the much smaller primary banks in providing complex, non-standard products and services to their customers. Moreover, they are truly universal banks in their own right providing commercial and investment banking services to larger domestic and foreign bank, non-bank and public clients. They thus compete directly with the large private commercial banks.

Most Land banks are owned by the respective state, by other Land banks ${ }^{13}$ and by the 13 regional savings associations. The main function of these regional associations is to provide administrative services to their members, the regional savings banks. They run seven data centers that employ more than 5,500 people, develop new financial products, conduct marketing campaigns and provide economic and market research insights, training, procurement and auditing services. As a link between savings banks and Land banks they also coordinate the activities between these two tiers of the group.

DGZ-Deka Bank is the central bank to all Land banks and together with the German Savings Bank Association (DSGV), in which all savings banks hold a stake, constitutes the third tier. Both the Land banks and the DSGV own 50\% of DGZ-Deka Bank. This institution fully controls the investment funds of the savings group, which had 136 billion Euro under management at the end of 2000, of which approximately 75 billion Euro were invested in retail funds resulting in a $20 \%$ domestic market share.

regulator are they permitted to offer their services outside their defined market.

11 For a detailed presentation of this argument from the angle of private sector banks, see for example Association of German Banks (2000), pp. 6.

12 See section 2.5 for a discussion of the main features of Pfandbriefe.

13 At the end of 2000, West LB, the largest Land bank, for example owned 39,9\% of Land bank Schleswig Holstein which itself owned $49,5 \%$ of Hamburgische Land bank. 
The savings bank group furthermore encompasses eleven regional public loan and building associations (market share in 2000: 34\%), eight leasing companies (21\%), two factoring companies (17\%), 37 public insurance companies (life assurance: 10\%; composite insurance: $14 \%)$ and 75 venture capital companies.

Except for the high degree of independence on the part of the primary savings banks granted by the "federal corporatist" type of organization, the form of labor division within the savings bank group resembles the hierarchical structure of the big four universal private sector banks with their headquarters, regional centers, branches and subsidiaries. Hence, the savings bank group could and maybe should be perceived as one large bancassurance entity. As such it constitutes the largest financial institution in the world with roughly 3,000 billion Euro assets at the end of 2000 .

Figure 4 shows the unconsolidated, domestic balance sheet and three performance indicators of the primary savings institutions and the Land banks for the past three decades. Because of their clear focus on traditional commercial banking, loans to non-banks represent the lion's share of the savings banks' domestic asset base. Their share has decreased only slightly from $65 \%$ in the 70 s to around $60 \%$ over the course of the 90 s and stood at $61 \%$ in 2000. In stark contrast, the share of deposits from non-banks in total liabilities has sharply decreased from $87 \%$ to $69 \%$ over the three decades and reached an all-time low of $62 \%$ at the end of 2000. As a consequence of these disparate developments, the role of savings banks as providers of funds to other banks has eroded over time.

Instead, in their totality savings banks became net-borrowers in the interbank market. This development is mirrored on the asset side of the Land banks, which lent an increasing portion of their funds to primary savings banks in the form of long-term money for the matched funding of their mortgages. Traditionally, Land banks obtained these funds though either bank debentures sold to private and institutional investors or through deposits from other banks. It is partly because of the increasing importance for Land banks of wholesale banking that they overtook the primary savings bank in terms of total assets in the late nineties and represented a fifth of total German domestic banking assets and $17 \%$ of total loans to non-banks in 2000 . The market share of savings banks in non-bank loans was only a little higher at $20 \%$. The combined market share of the savings bank group in non-bank loans fell slightly from $43 \%$ in the seventies to below $40 \%$ in the late nineties.

Figure 4: Balance sheet and performance indicators of the savings bank group (1971-2000) 
a) Primary savings banks

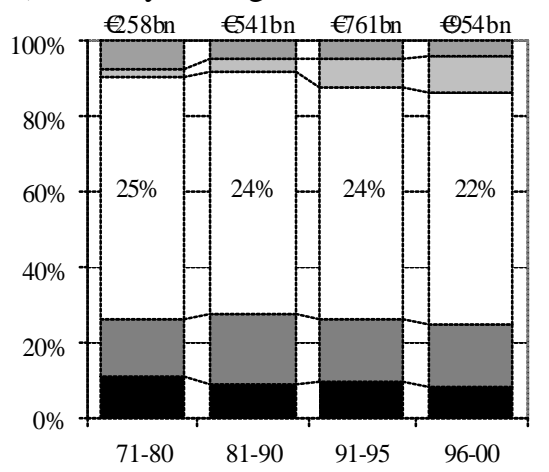

b) Landbanks

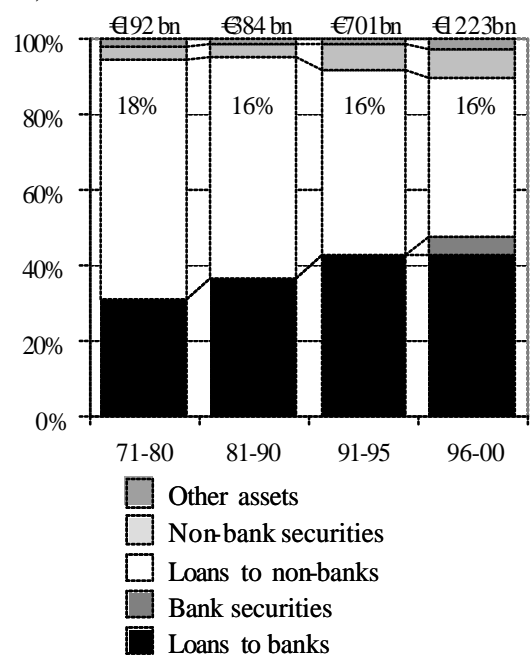

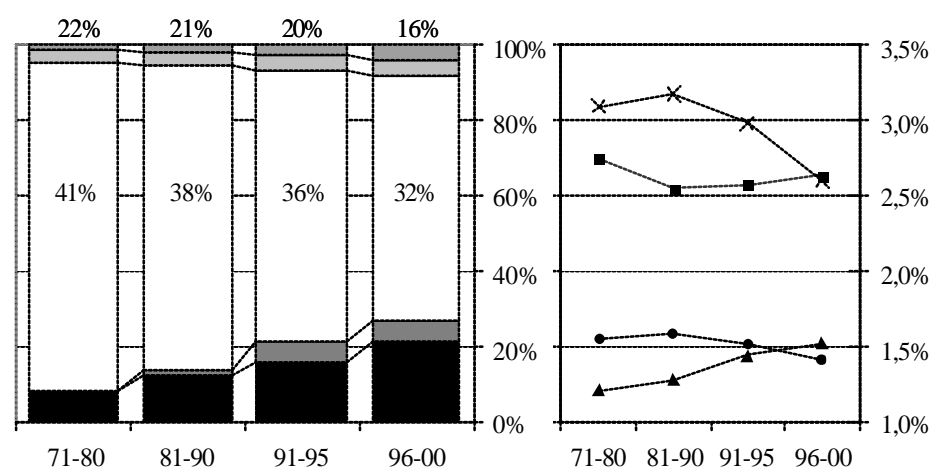

$\begin{array}{lrrr}71-80 & 81-90 \quad 91-95 \quad 96-00\end{array}$

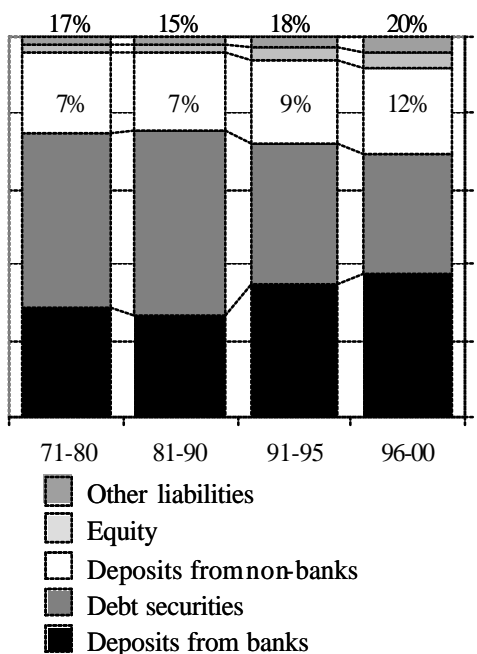

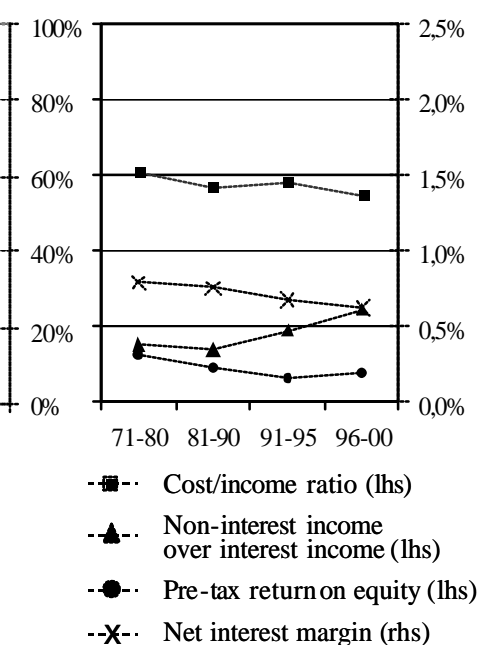

For notes and source please refer to Figure 3.

The high interest margin of savings banks is certainly due to their strong focus on retail banking (i.e. offering savings products to households and loans to individuals and small and medium-size enterprises (henceforth SME)) and in particular to the economic rents from an inert deposit base. Even though savers became more price sensitive during the nineties and thereby caused margins to drop to $23 \%$ in 2000 , margins are still more than three times higher than those of private commercial banks with their stronger focus on the commercial banking business with larger clients. Not surprisingly, the ratio of non-interest income to interest income (slightly more than $20 \%$ in 2000) of both savings banks and Land banks is much lower than it is for the private sector banks. What may come as a bit of a surprise, however, is the fact, that the cost/income ratio for the savings bank sector as a whole $(60 \%)$ was considerably lower in the late nineties than for the profit-maximizing private commercial banks (well over 70\%). Given that the savings banking sector is the undisputed market leader 
in German retail banking, this points to a lack of scale for private sector banks' retail banking operations. ${ }^{14}$

\subsection{Co-operative banking group}

In the early $19^{\text {th }}$ century German craftsmen and farmers suffered from dire financial constraints because the existing private bankers were largely focusing on trade finance, private commercial banks were mainly granting loans to the manufacturing and transportation industry, and savings banks had to request collateral in exchange for credit. Starting in 1850, credit co-operatives were founded under the basic principles of self-aid, self-responsibility and autonomous administration to mitigate these constraints. The savings of depositors were transferred to members with financing needs and once a year the profits of a credit cooperative were distributed among its members. Nowadays, profits are still paid out to members - whose number reached 15 million in 2000 - but since 1974, non-members have also become eligible to receive loans. In 1972, all German credit co-operatives were united to form the German Association of Volks- and Raiffeisenbanks, which shares many structural features with the German Association of Saving Banks. The multi- tier structure comprises the primary credit co-operatives that provide mainly retail banking services to their local market. Their member individuals can exercise their control rights at members' meetings and via a supervisory board. Like the Land banks, the two central institutions of the co-operative banking group - the WGZ bank and the DZ-Bank 15 - provide a wide array of services to their primary institutions. They act as clearing institutions, provide access to national and international financial markets, provide asset liability management support and offer centralized back-office functions. In addition to their functions as the central body they compete with the larger private sector banks in the investment and commercial banking arena. The co-operative banking group also includes two mortgage banks, one leasing company, one building and loan association, one insurance company and an investment company with approximately 60 billion Euro retail funds under management and a 16\% market share at the end of 2000. The combined asset base of the group amounted to 920 billion Euro making it

\footnotetext{
14 Other indicators that underscore this view are risk-weighted assets per branch, loans per branch and loans per employee. According to estimations by Morgan Stanley Dean Witter (2000), the value of all three ratios were far lower on average for the retail operations of the four big private sector banks than for the largest savings banks in 1998. Small market shares seem hence to translate into the inability of the private sector banks to generate sufficient retail business volume to cover the fixed costs of branch networks.

15 In 2001, DG Bank, the former apex institute of the co-operative banking group merged with GZ-Bank, one of two former regional co-operative central banks, to form DZ Bank.
} 
only slightly smaller than the entire Deutsche Bank Group. With its customer base of 30 million, it clearly exceeds Deutsche Bank’s German 7,2 million customer base.

Figure 5: Balance sheet and income statement of credit co-operatives (1971-2000)

a) Primary co-operative banks
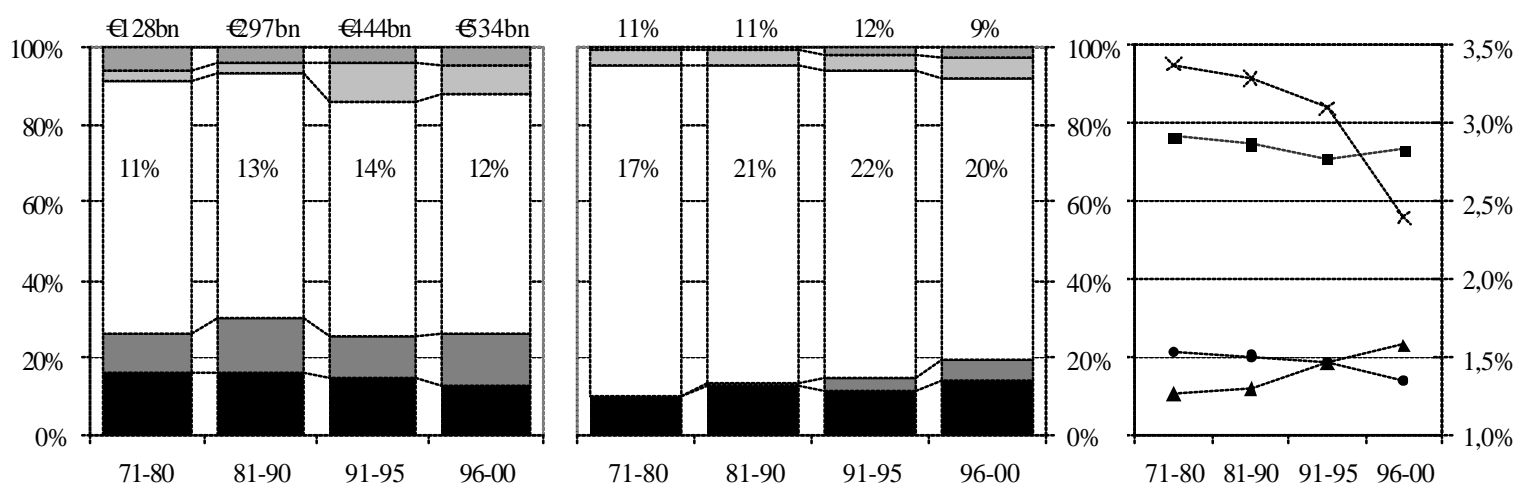

b) Regional institutions of co-operative banks
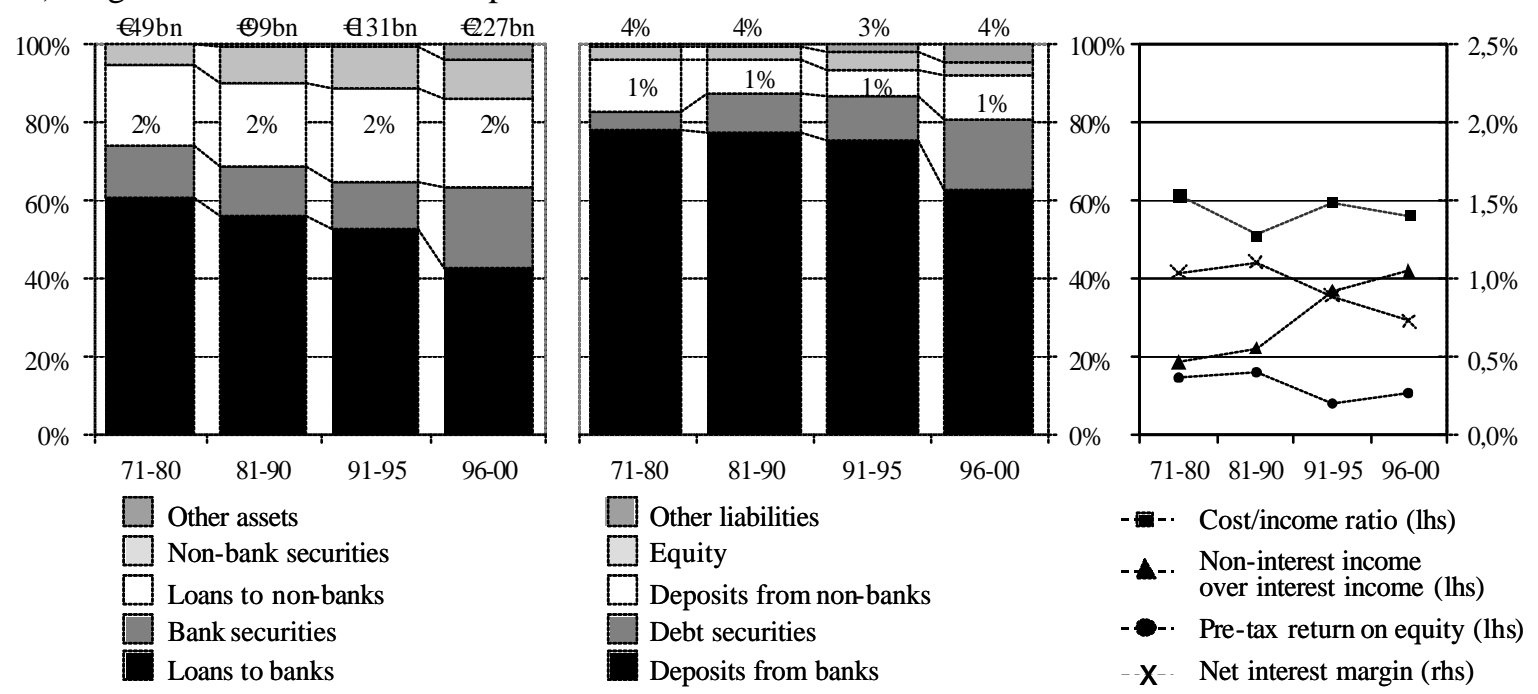

For notes and sources please refer to Figure 3.

The small size of the primary institutions brings with it the competitive advantages of customer proximity and quick decision making. However, in combination with the legal restriction that equity can only be raised from the co-operative members, the small size in itself also curbs the loan business with larger enterprises and in effect precludes further profitable growth. The intense within-group M\&A activity that has brought down the number of credit co-operatives from over 11,000 in 1970 to less than 1,800 at the end of 2000 can be partly explained by this fact. Of course, in many cases the need to exploit economies of scale, to better diversify the loan portfolio or to rescue weak peer institutions have also played an important role. However, as can be seen from Figures 4 and 5, the average cost/income ratio 
of the credit-co-operatives has hardly decreased during the last thirty years and consequently is still higher than that of the savings banks.

With respect to balance sheet structure, the interest margin, the importance of non-interest income and pretax ROE, both levels and changes during the last decades are fairly comparable to those observed for the primary savings banks (see Figure 5); the drop in interest margins resulted in non-interest income exceeding $20 \%$ of interest income and has caused pretax ROEs to fall below $20 \%$ in recent years.

The balance sheet structure of the regional institutions of co-operative banks demonstrates their role as central banks for the primary institutions. More than $60 \%$ of their assets and also more than $60 \%$ of their liabilities are claims on other banks and funds owed to other banks, respectively. In the second half of the nineties the three banks increasingly substituted bank loans and deposits by purchasing bank securities and issuing bearer bonds. Interest margins fell below $1 \%$ and because of an increase in investment banking activities fee and trading income rose to over $40 \%$ of interest income. At the end of 2000 the entire co-operative banking sector had a market share in total domestic banking assets of $13 \%$. Their market share in loans to non-banks and in deposits from non-banks has risen slightly over the course of the last 30 years.

\subsection{Special banks}

Special banks accounted for $22 \%$ of all German banking assets at the end of 2000. More than $15 \%$ were controlled by 31 mortgage banks alone; among them four public mortgage banks, of which only the Westdeutsche Immobilienbank (rank 62) appears on the list of Germany's top 100 banks. However, seven of the private mortgage banks rank among Germany's top 30 banks. In late 2001, the mortga ge banking subsidiaries of Deutsche Bank (Eurohypo), Dresdner Bank (Deutsche Hypothekenbank) and Commerzbank (Rheinhyp) merged to create Germany's largest mortgage bank with a $25 \%$ share in the German mortgage market and roughly 240 billion Euro in total assets, catapulting the new entity into Germany's top 10. The three big banks acknowledged as their main motives to be to cut costs, to free up capital and to achieve the critical size for competing in the European market. According to the German mortgage bank law, mortgage banks are restricted in their business mix to granting loans, either backed by liens on property or by assets and tax income of public authorities, and to refinancing those loans by means of long-term deposits and bank debentures such a commercial and public Pfandbriefe. Commercial (public) Pfandbriefe are backed by a pool of 
residential or commercial mortgage loans (loans to and securities issued by public sector borrowers). Bond holders have a pari-passu first charge over the entire collateral pool and the mortgage bank remains liable if the assets in the pool turn out to be insufficient to meet any obligation arising from its Pfandbriefe outstanding. As a consequence of the strict legal framework provided by the German Pfandbrief law and the German mortgage bank law ${ }^{16}$, not a single Pfandbrief defaulted during the $20^{\text {th }}$ century. Especially since 1995 , when so called Jumbo-Pfandbriefe with a volume of over Euro 500 million per single issue were introduced, the German Pfandbrief-market has witnessed impressive growth. The volume of outstanding Pfandbriefe has almost doubled between the end of 1994 (Euro 420 billion) and the end of 2001 (Euro 820 billion), making German Pfandbriefe the largest segment in European bond markets. ${ }^{17}$

At the end of 2000, $62 \%$ of German mortgage bank assets were loans to non-banks, $19 \%$ were deposits with other banks, $8 \%$ were non-bank securities and $7 \%$ were bank securities. $67 \%$ of total liabilities were in the form of bank debentures (mostly Pfandbriefe), $16 \%$ were in the form of deposits from non-banks and $12 \%$ were in the form of deposits from other banks. For the same year the cost/income ratio was 33\% and the pre-tax ROE reached an all-time low of $4,6 \%$ after it had averaged $13 \%$ over the nineties and $15 \%$ over the eighties.

The 30 German building and loan associations accounted for merely 2,5\% of total German bank assets at the end of 2000. However, $12 \%$ of all time and savings deposits and $13 \%$ of all mortgage loans to German individuals were deposits and loans, respectively, under savings and loan contracts. After signing such a contract with a building and loan association, the customer enters the savings phase during which he makes constant monthly payments. After the minimum savings amount has been accumulated (typically $40 \%$ of the total contract sum) and subject to a customer-specific amount exceeding a threshold value, the customer is allotted the mortgage loan. During the second phase of the contract duration, the customer repays his loan and thereby replenishes the society's capital pool. After a sufficient number of periods this construction yields a closed system so that interest rates on deposits and on loans can remain almost constant across time.

\footnotetext{
16 For example, the mortgage bank law requires that mortgages eligible as commercial Pfandbrief pool collateral must not exceed $60 \%$ of a property's mortgageable value, that properties must be marketable and conservatively valued, and that total mortgages for financing building plots and uncompleted buildings not yielding income as well as total mortgages against real estate in countries, which do not accept preferential satisfaction of bondholders, must not exceed $10 \%$ of the total mortgage pool each.
}

17 See Maestroeni, O. (2001) for further details. 
The 16 German banks with special functions have in common that they grant loans to individuals, enterprises and projects that are deemed eligible for promotion by the German government. The private Industriekreditbank, for example, promotes SMEs that would otherwise not have access to capital markets. The private Liquiditäts-Konsortialbank, which is backed by all German universal banks, acts as a drawee for bills of exchanges drawn by banks that suffer from liquidity shortages. Also backed by other German banks, the AKA Ausfuhrkreditgesellschaft promotes German enterprises through export finance and direct loans to their foreign customers. The public-owned Kreditanstalt für Wiederaufbau (KfW) provides services in the areas of investment finance (e.g. structural investment programs in the eastern part of Germany), export and project finance and financial cooperation with developing countries. Its subsidiary DEG promotes private-sector initiatives in developing and reforming countries. The combined asset base of all banks with a special function amounted to $7,5 \%$ of total domestic assets in 2000 .

\section{Major trends in the German banking market}

This section outlines some of the major trends in the German banking market and compares them to developments in other European countries and the US. Based on the presented, and admittedly crude, evidence we attempt a preliminary assessment of whether German (and European) commercial banking is indeed in the middle of structural change and if so, whether it is in decline.

Figure 6: Number of banks and branches in Germany (1970-2000)

a) Number of bank institutions in Germany

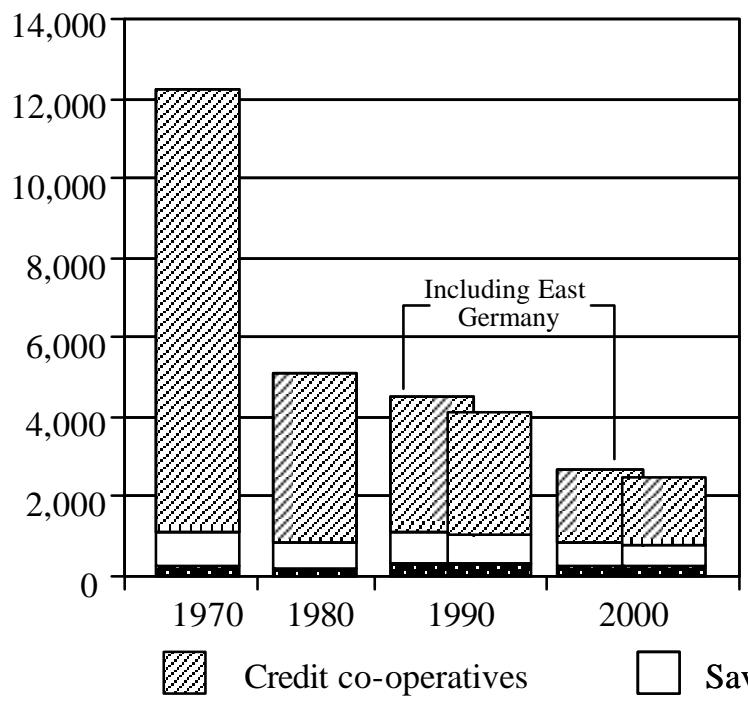

b) Number of bank branches in Germany

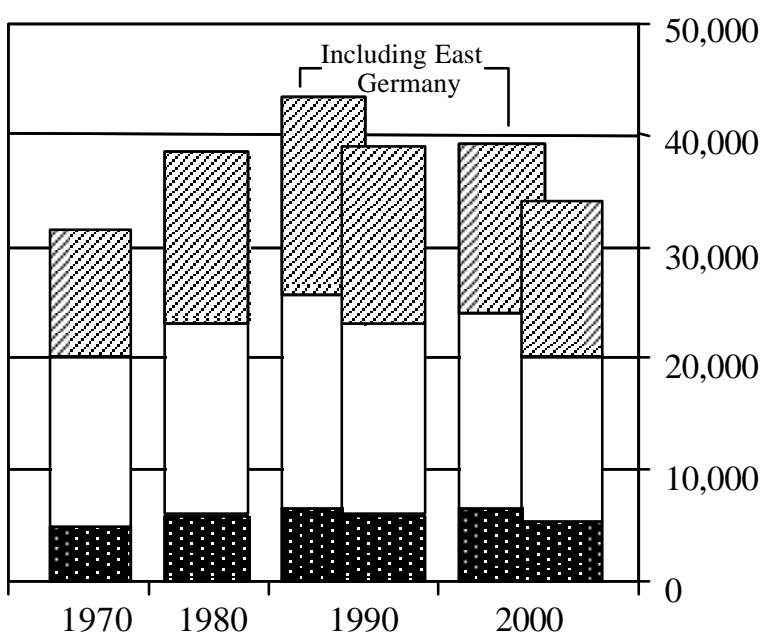

Private commercial banks

Source: Deutsche Bundesbank 
Figure 6 shows the development of the number of commercial, savings- and co-operative banks and their branches during the last thirty years. The total number of banks has decreased dramatically from more than 12,000 during the seventies to roughly 5,000 in the year 2000 . This was mainly due to the consolidation within the co-operative sector. During the last 20 years, the total number of West German universal banks has been further halved to about 2,500. Again, the absorption of very small or stressed financial institutions by a sounder member of the co-operative or the savings banking group, respectively, was responsible for the lion's share of this reduction. In contrast, the number of branches (excluding those of the postal bank) increased considerably during the seventies and eighties reaching a peak of over 40,000 in the early nineties. Even when Eastern German branches are excluded their number was still higher than it had been ten years earlier. This has prompted many commentators to declare the German financial system to be over-banked.

Since 1990 the number of branches in the three major banking groups has come down to under 39,000, with the sharpest fall in the western parts of Germany, where about 5,400 branches were closed by 2000. Mainly responsible for this decline were the savings banking and the co-operative banking groups, which trimmed down their branch network by $15 \%$ and $13 \%$, respectively. Similar trends could be observed in the EU14 countries (excluding Luxembourg), in the UK and the US for the period from 1985 to $1999 .{ }^{18}$ Except for Greece, Ireland and the Netherlands, where less than 100 banks existed in 1985, the number of banks decreased in all these countries. For example, in Spain and France, the number of banks dropped by about $45 \%$, in the US by almost $40 \%$ and in Italy and the UK by slightly more than $25 \%$. As a result, the proportion of German banks in relation to the total number of European banks has remained more or less constant at almost $40 \%$ during the last 20 years. The consolidation wave led to an increase in the market share in terms of assets of the five largest banks in the majority of European countries. As a result, the average ratio increased from 53\% in 1985 to $57 \%$ in 1999 , with Sweden (88\%), the Netherlands (82\%), Belgium (77\%) and Denmark (77\%) showing the highest values in 1999. Also with respect to branch network density, the German trend mirrors the general European trend. While the number of German branches per 1000 capita fell from 0.61 in 1985 to 0.54 in 1999, the European average has declined from 0.49 to 0.45 . Germany now ranks $4^{\text {th }}\left(1985: 5^{\text {th }}\right)$ in terms of this ratio with higher values only for Spain (1.0), Belgium (0.68) and Austria (0.57) and hence

\footnotetext{
18 The figures reported in this and the next paragraph are taken from ECB (2000).
} 
might still be considered as over banked by European and also by US ${ }^{19}$ standards. The German banking association itself states in its 2002 banking survey (p.70) that the number of bank branches exceeds that of gas stations by the factor 4 and quotes internal studies according to which the break-even point for retail operations lies below 0.25 branches per 1000 capita.

The following two figures encapsulate major trends in the profit and loss statements of European and US banks during the 15 years between 1985 and 1999. Interest margins deteriorated in all seven countries indicating an intensification of competition within the banking industries an/or from non-bank financial intermediaries and capital markets. ${ }^{20}$ In 1999, only French interest margins were thinner than those in Germany. It might therefore be argued that the degree of competition among German banks is neither lower nor higher than in the other major countries. Declining interest margins have caused banks to seek alternative sources of income.

Figure 7: Net interest margins and non-interest income contributions (1985-1999)

a) Net interest income/total assets

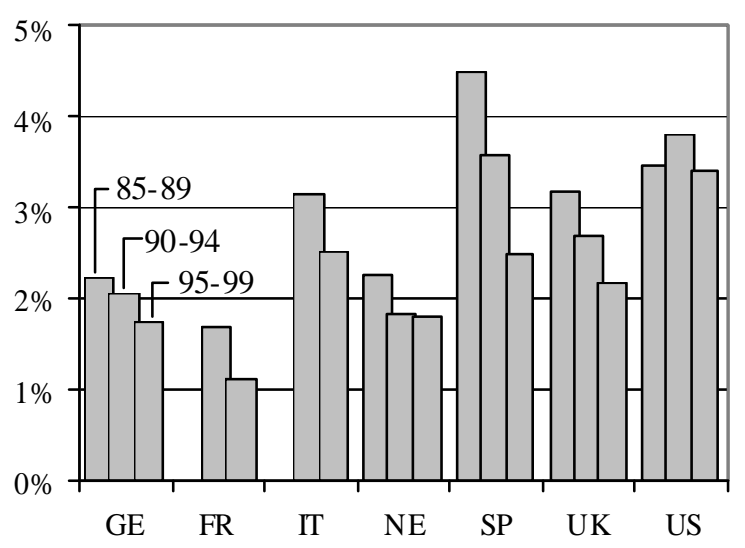

b) non-interest income/interest income

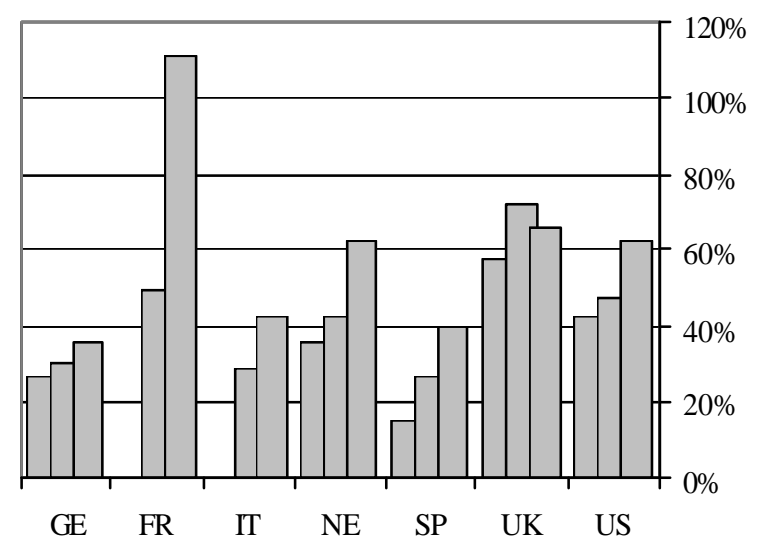

Note: Data for all banks in the case of GE (Germany), FR (France), IT (Italy), NE (Netherlands), SP (Spain) and for commercial banks only in the case of US and UK.

Source: OECD $(1995,2000)$

Consequently, and as can be observed from panel b) in Figure 7, the relative importance of fee-based businesses like asset management, underwriting and advisory services as well as trading activities has risen in all countries. Not surprisingly, this trend has been the strongest in France, where margins were the lowest during the nineties. However, even in the US,

19 According to White (1998) the corresponding figure for the US was 0,27 in 1996. 
where banks enjoyed above-average interest margins during most of the observation period, the ratio increased considerably. These developments can be interpreted as general evidence of a global shift in the focus of banks from traditional commercial banking towards more capital market-oriented services. Although German banks have started to catch up, they still seem to be far behind in this regard.

Because of their successful efforts in cutting costs (see panel b) in Figure 8) the AngloSaxon banks have managed to translate this shift into higher returns on equity. German banks have been less successful in reducing operating expenses and as a result have suffered from declining returns. In both respects they hold a middle position among their European peers.

Figure 8: Return on equity and cost/income ratios (1985-1999)

a) Profit before tax/equity

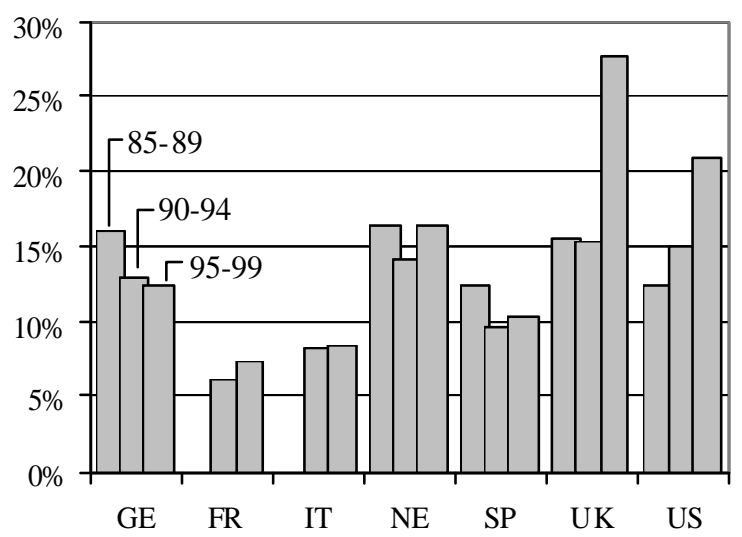

b) operating expenses/gross income

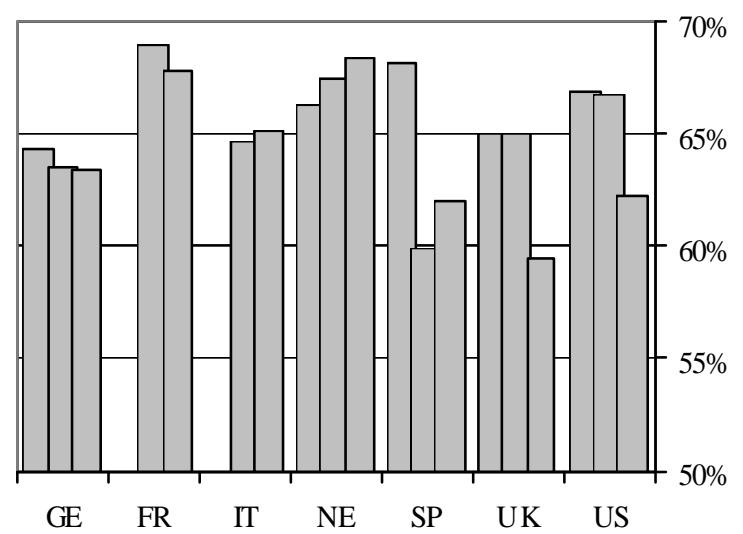

rce: $\operatorname{OECD}(1995,2000)$; for notes see Figure 7

Taken together the evidence presented so far seems to corroborate the common belief that traditional commercial banking is in decline all over the world and that German banks are no exception to this rule. ${ }^{21}$ However, the empirical evidence that is presented in the next section casts crucial doubts on this view.

20 Dermine (2002) shows that for many European countries this drop in net interest margins is primarily due to a squeeze in deposit margins, which in turn is also owed to lower general interest rate levels. Margins on consumer and corporate loans were found to have actually increased in many cases.

21 Advocates of this view often cite as further evidence the shrinking share of banking assets in total financial sector assets. Allen/Santomero (2001) show for the US that this share has halved from over $60 \%$ in 1960 to below 30\% in 1998. Data from the German and British National Accounts Statistics reveal that the equivalent German figure declined from over $80 \%$ to about $70 \%$ and that the share for the UK declined from $65 \%$ to below $50 \%$ during the eighties and nineties of the last century. 


\section{Reports of the death of commercial banking might be exaggerated}

In analyzing the role of commercial banks in any given country it might indeed be misleading to only assess figures pertaining to the banking industry itself. Rather, the importance of banks for the other sectors of an economy should also be measured. Intermediation ratios and securitization ratios provide very helpful instruments for this purpose. ${ }^{22}$ Their definition and measurement are based on the concept of an economy as a set of sectors that interchange goods, services and, most importantly for our context,: financial funds. Accumulated over time these financial flows between economic sectors translate into financial claims of one sector and an offsetting liability item of another sector. Because this concept focuses on sectors and not on single economic units, only inter-sectoral, and not intrasectoral, claims and liabilities, such as a loan from one bank to another bank, are considered. Intermediation ratios measure the proportion of sectors' total financial assets and liabilities, respectively, that constitute claims on financial institutions (asset intermediation ratios) or liabilities vis-à-vis financial institutions (liability intermediation ratios).

Securitization ratios take an instrumental perspective and measure the proportion of total claims and liabilities, respectively, that take the form of securities. In both cases ratios can be computed for different aggregation levels. So-called general intermediation ratios indicate the importance of domestic financial intermediaries for all non-financial sectors, i.e. households, enterprises, the non-financial public sector and all foreign entities. Partial intermediation ratios can be computed along three lines, i.e. either by focusing on claims or liabilities of one non-financial sector vis-à-vis all financial intermediaries, by focusing on claims or liabilities of all non-financial sectors vis-à-vis one particular type of financial intermediary, or by employing a combination of these two approaches. Likewise, securitization ratios can be computed for all or a selection of non- financial sectors.

\footnotetext{
22 The ratios are computed from National Account statistics, which the Deutsche Bundesbank describes as a unified data set which indicates from whom and to what extent funds of a specific type are channelled through a financial system, and what types of financial institutions are involved in this financial circuit [Deutsche Bundesbank (1995), p. 7]. Structural differences in the data from different central banks and statistical offices with respect to subsector definition, degree of consolidation of items and general data reliability made data adjustments necessary. A discussion of adjustments and the estimated effects of remaining incongruencies can be found in Hackethal (2001). The ongoing process of standardizing compilation methods across countries will eliminate most methodological shortcomings. At the same time, however, historical comparisons will become more complicated as the changes imply structural breaks in the time series. For precisely this reason, it has not been possible to specify French and Japanese intermediation and securitization ratios for the years 1997/1998 and 1998, respectively. For data availability reasons, updating the UK ratios beyond 1995 was not possible, either. Please refer to Hackethal (2001) for a further discussion of the methodology and the data set and for a presentation of US and Japanese ratios prior to 1980.
} 
Figure 9, panel a), shows the proportions of claims on the financial sector relative to the total claims of all non-financial sectors for the five largest economies in the world. Because financial assets of the entire financial sector must by definition roughly equal financial liabilities, these proportions must equal the respective proportions of liabilities vis à vis the financial sector in total liabilities. Except for France, where the ratio decreased from about $60 \%$ to $50 \%$, the role of financial intermediaries remained largely constant or - as has been the case in the US - even increased during the eighties and nineties. Hence, financial and monetary integration, technological advances and deregulation have certainly not led to a general trend of disintermediation. However, as can be seen from panel b), these external factors have improved the sophistication of organized capital markets and have thus resulted in a strong increase in the proportion of securities, i.e. stocks, bonds, commercial paper, and investment certificates, in the portfolios of the non-financial sectors of three of the five countries. As securitization ratios are computed based on market values of securities, the burst of the bubble in Japanese equity markets led to a drop in the respective ratio in the early nineties. It is interesting to note that the US ratio reached a level in 1998 which it had already had in 1970 and which in turn was still a long way away from the $60 \%$ it had had in the early sixties. As claims on pension funds and life assurance companies were counted as nonsecuritized claims, British securitization ratios are biased downward. Had they been counted as securitized claims, the British ratio would have reached a level comparable to that of the US. Indeed, the liability securitization ratio of British non-financial sectors increased from $35 \%$ at the beginning of the eighties to almost $50 \%$ in 1995, indicating the increasing role of these institutions as investors in corporate equity and government bonds. The corresponding ratios also rose sharply in France (from 31\% to 65\%) and Germany (from 11\% to 33\%) and to a lesser extent also in the US (from $59 \%$ to $66 \%$ ) and Japan (from $25 \%$ to $26 \%$ ). 
Figure 9: General asset intermediation and securitization ratios (1981-1998)

a) Asset-intermediation ratios of all sectors

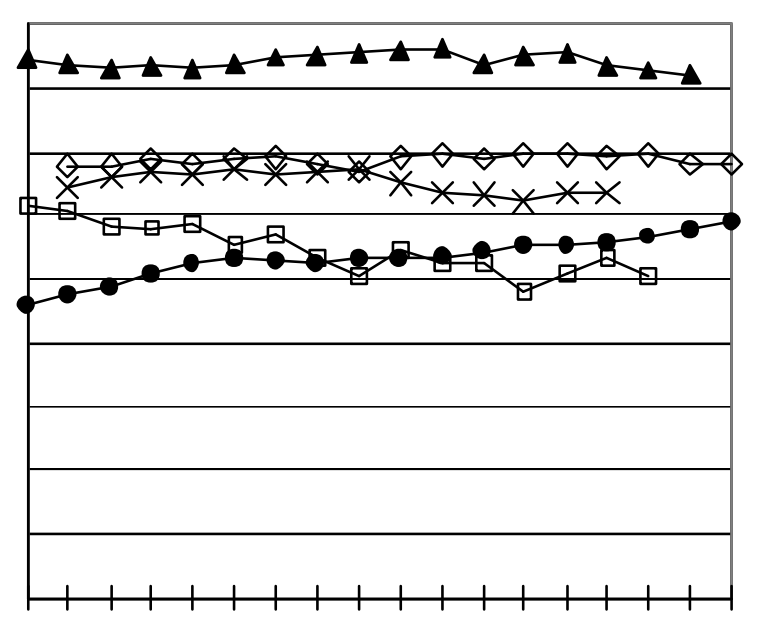

818283848586878889909192939495969798 b) Asset-securitization ratios of all sectors

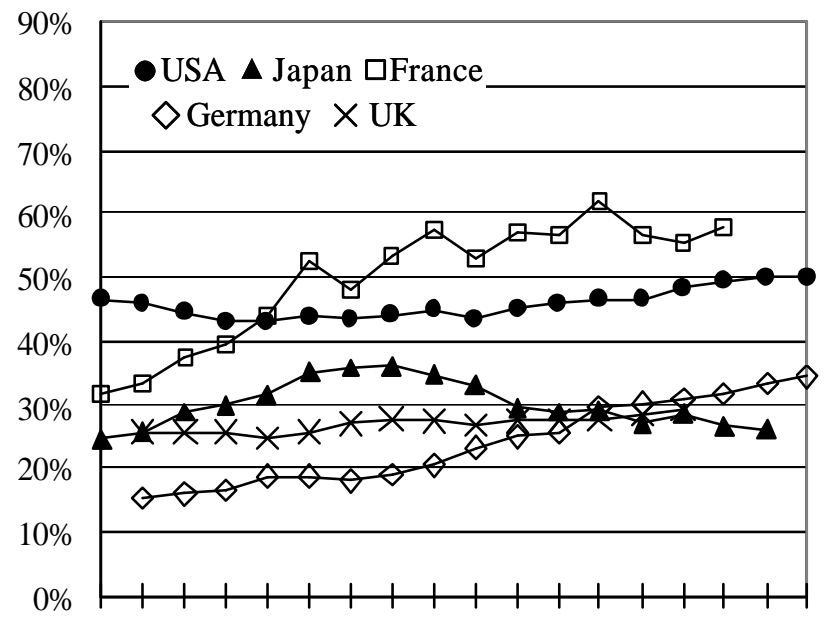

818283848586878889909192939495969798

Source: National Account Statistics

The two main observations concerning stable general intermediation ratios and increasing securitization ratios can be reconciled by taking into account the increasing role of non-bank financial institutions (NBFI) like insurance companies, pension and investment funds and the upward trend of stock markets in all countries except Japan during the nineties.

This becomes apparent in Figure 10, panel a), which shows the proportion of household claims on banks to total household claims for the five countries. The downward trend is largely comparable to the trend for the asset intermediation ratios of all non-financial sectors vis-à-vis banks (see Hackethal 2001). It is more pronounced only because households constitute the main surplus units in all countries. ${ }^{23}$ Clearly, the role of banks as collectors of surplus capital from non-financial sectors declined in all five countries.

23 Especially in the case of the UK, where many banks are heavily involved in interbank transactions with foreign banks, the sector "Rest of the World", which itself encompasses all of these foreign counterparts, drives the general intermediation ratios. Partial ratios of households and enterprises are thus much more representative of UK banks' role within their domestic financial system. 
Figure 10: Bank-intermediation ratios (1980-1998)

a) Asset-intermediation ratios of households

b) Liability intermediation ratios of banks vis-à-vis banks
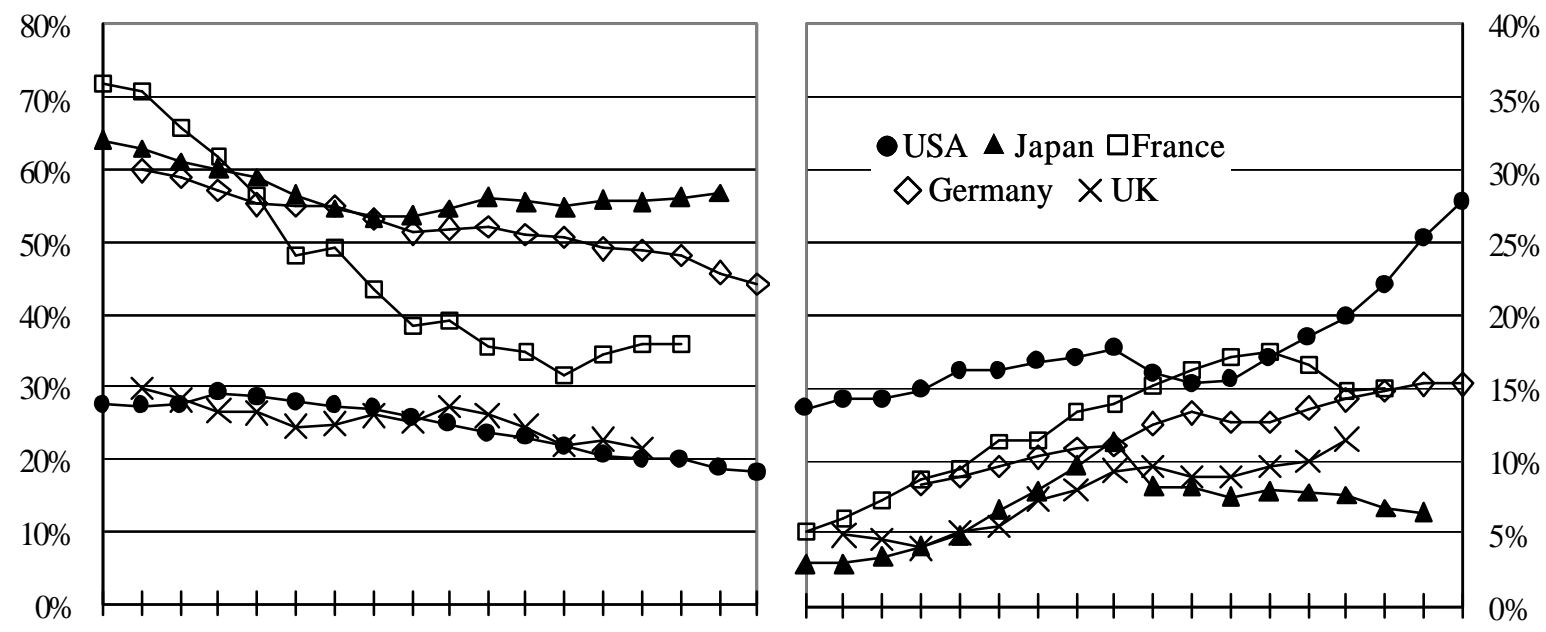

818283848586878889909192939495969798818283848586878889909192939495969798

Source: National Account Statistics

As total asset intermediation remained fairly constant, NBFIs must have gained market share at the expense of banks. Bank disintermediation on the asset side of households is thus a phenomenon that all observed financial systems share in common. It is important to note, however, that the level of bank intermediation still differs remarkably between those countries which have traditionally been deemed to be bank-based, namely Japan and Germany, on the one hand and the capital market-based Anglo-Saxon countries on the other hand. ${ }^{24}$ France is the exceptional case, in that its financial system seems to have evolved from being largely state-controlled and bank-based to a system in which marketable instruments have gained great importance to the detriment of intermediated instruments in the area of firm financing and, in particular, in the area of long-term saving. 25

As the non-financial sectors restructured their portfolios by switching from bank deposits into insurance contracts, investment certificates and stocks, most banks had to seek alternative refinancing sources. Figure $10 \mathrm{~b}$ reveals that as a consequence, the portion of funds from NBFI, whether in the form of deposits, money market instruments, bank debentures or equity in total bank liabilities, rose sharply in all five countries. In combining both insights from Figure 10 it can be concluded that asset-intermediation chains lengthened everywhere. NBFI

24 A standard source for the classification of financial systems into bank- and capital market-based systems is Rybczynski (1984).

25 Refer to Schmidt et al (1999) and Schmidt et al (2002) for a further discussion of the "exception Française”. European Central Bank (2002) contains a discussion of recent developments in the French financial system and presents data for the year 2000 . 
moved in between surplus units and banks and in turn, invested part of the collected capital with banks. This certainly increased refinancing costs for banks leading to a fall in interest margins as shown in Figure 7. The effect on overall profitability, however, was probably smaller for German and French institutions than is indicated by Figure 8. Unlike their AngloSaxon peers, German and French banks own the dominant players in their domestic investment fund market so that decreasing net interest revenues were at least partially offset by increasing contributions from asset management operations, which, however, do not fully show up in the OECD-statistics.

Figure 11: Role of bank finance for non-financial enterprises

\section{a) Liability intermediation ratios of enterprises vis à vis banks}

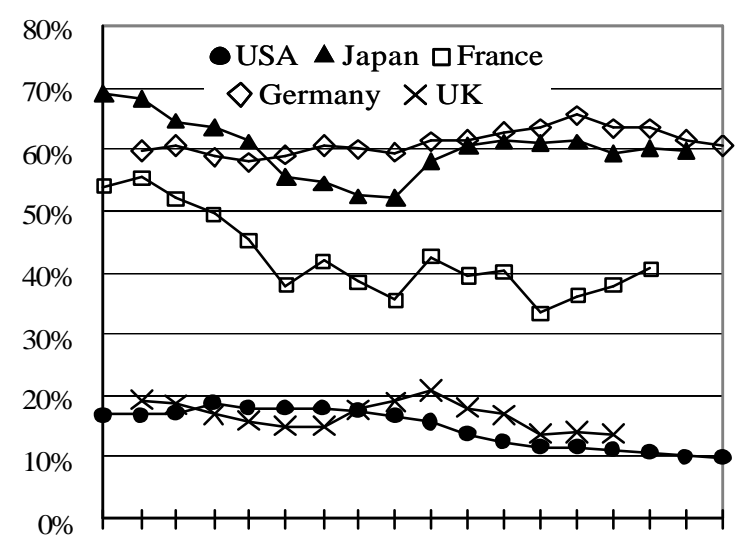

818283848586878889909192939495969798 b) Bank loans/total liabilities of German enterprises (DM-turnover classes)

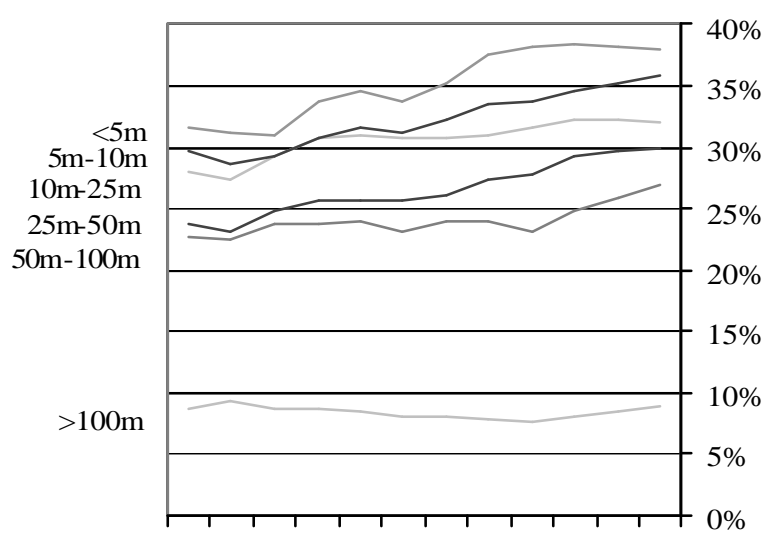

899091929394959697989900

Source: National Account Statistics and Deutsche Bundesbank (2001b, 2002)

In four of the five countries, bank intermediation also declined in importance from the debtors' perspective. Figure 11a shows an almost parallel development of the fraction of the inter-sectoral liabilities of British and US non-financial enterprises that are owed to banks. Bank loans, commercial paper, corporate bonds and corporate equity held by banks constituted only about $10 \%$ of enterprises' total inter-sectoral liabilities at the end of the observation period. Albeit from a higher level, bank finance in this wider sense has declined 
in France and Japan. ${ }^{26}$ In sharp contrast, German enterprises still rely heavily on banks as financiers. The ratio has remained roughly constant at $60 \% .27$

Figure $11 \mathrm{~b}$ shows the results of a closely related study conducted by the Deutsche Bundesbank, which was based not on National Account Statistics but on detailed balance sheet data of about 20,000 German enterprises. Because of the inclusion of inter-sectoral liabilities and the fact that bank finance could only be extracted in the form of bank loans the levels of the ratios are much lower than the corresponding liability intermediation ratios vis-àvis banks in panel a). The reported change in the ratio of bank loans to total liabilities for German enterprises from six different size classes is, however, of great help in explaining the extent to which German banks should still be considered unique. Whereas enterprises with annual sales exceeding DM 100 million have emancipated themselves slightly from bank loans, German SMEs have even increased their reliance on bank loans. Because the magnitude of information asymmetries is generally negatively correlated with firm size, this trend implies rising demand for the monitoring capabilities of German banks. ${ }^{28}$

We can thus conclude that the predominant role of the Mittelstand for the German enterprise sector in conjunction with its preference for financing investments by means of bank loans is responsible for the fact that bank disintermediation cannot be observed on the asset side of the German banking sector as whole. As mentioned in section 2.2, the big commercial banks have traditionally been the Hausbanks to large corporations, whereas the savings banks have typically played the Hausbank role for SMEs. In conjunction with the observed increase in demand for loans by SMEs this might explain why the savings bank group was able to extend its market share in corporate loans from 30\% in 1990 to $39 \%$ in

\footnotetext{
26 A study by Morgan Stanley Dean Witter (2000, p. 81) indicates that the liability intermediation ratios vis -àvis banks of Spanish and Italian enterprises also declined strongly during the nineties.

27 A widely recognized series of studies initiated by Mayer (1988) led to a profound revision of academic thinking about the financing patterns of corporations in different countries. Using netted flow-of-funds data instead of balance sheet data, the studies found that internal financing is the dominant mode of financing in all countries, and that financial patterns do not differ very much between countries. Corbett/Jenkinson (1997, p.85) conclude: "The celebrated distinction between the market-based financial pattern of the United Kingdom and the United States and the bank-based pattern of Germany is inaccurate". Hackethal/Schmidt (2002) demonstrate that the surprising empirical results found by Mayer et al. are mainly due to a hidden assumption underlying their methodology. Based on an alternative method that uses gross flows instead of net flows, Hackethal/Schmidt find that financial patterns are very much in line with the commonly held belief prior to Mayer's contribution and that gross-flow financial patterns can indeed be easily reconciled with the financial structures shown in Figure 11.

28 This point is also stressed by Edwards (1996), p. 64: "[The] monitoring advantage is probably greatest with respect to small business borrowers, where problems of asymmetric information are particularly severe and where banks commonly provide those firms with unsecured credit".
} 
$2000^{29}$. During the same period, the market share of private commercial banks dropped from $37 \%$ to $29 \%$, whereas the market share of the co-operative sector remained almost constant at around $15 \%$. Apparently, the big universal banks have been withdrawing from traditional commercial loan business and attempting instead to refocus on commercial banking to larger corporations and corporate investment banking like underwriting, trading and advisory. Retail banking is conducted mainly for synergy reasons, i.e. to exercise control over a distribution channel for products originating and/or managed in other parts of the bank. In line with this strategy - which Deutsche Bank calls "connectivity strategy" - the private commercial banks dominate the market for security deposits, administering more than $40 \%$ of the 34 million security deposits of German individuals in 2000. In terms of the market value of security deposit holdings, their market share was even higher at almost $60 \%$, indicating that the average wealth and propensity to invest in securities of their customers exceeds that of the customers of the other banking groups. Moreover, through their complete ownership of investment companies they controlled $42 \%$ of the mutual investment fund market in Germany. Private commercial banks were also quicker to adopt new technologies. Their share in the 15 million German online accounts that existed at the end of 2000 amounted to $49 \%$. 1.3 million of these online accounts were held with the four online brokerages of Germany's four big banks and another 530,000 with Consors, which had been founded by the small Nuremberg Schmidt bank and was bought by BNP Paribas in early 2002, making Germany the biggest online brokerage market in Europe by far.

These numbers stand in sharp contrast to the much smaller share of private commercial banks in demand deposits (30\%), and in savings deposits (15\%), in particular. In 2000, savings banks dominated these markets with market shares of $47 \%$ and $54 \%$ respectively, forcing private sector banks to rely on other, more costly refinancing sources (see Figure 3).

In the light of this clear dominance by savings banks in conventional retail banking to individuals and SMEs, the assessments of German big banks' CEOs, with which this paper started out, seem indeed to be justified. Public banks' favorable refinancing conditions due to

29 According to a press clipping of the savings bank group from March 15, 2002, the savings bank group granted $86 \%$ of all new loans to German enterprises and to the self-employed in 2001 and thereby increased its market share further to over $41 \%$. Its market share in loans to the German craft sector is estimated to be even higher at around 65\% (DSGV 2001). 
a strong core deposit base - and in the case of Land banks certainly also due to state guarantees - in conjunction with long-term and close customer relationships allow them to price corporate loans very aggressively. As a result, the big private sector banks suffer from razor-thin interest margins and possibly also from a lack of scale ${ }^{31}$, both of which preclude them from compensating for the high fix costs of their still extensive branch network. Given the fact that their commercial banking operations no longer create sufficient value on a standalone basis, and given the increasing pressure from institutional investors to create value, they are seeking new business opportunities in areas where their international reach and their sheer size warrants competitive advantages, namely in capital-market oriented areas. This puts them in direct competition with other, primarily Anglo-Saxon bulge bracket banks and thus implies a convergence in their market and resource-based strategies towards international standards. Viewed from this perspective, indeed no stone has been left unturned as far as large German private sector banks are concerned, and traditional commercial banking seems to be in decline like everywhere else.

We would argue, however, that exogenous factors have not been the most important reason for this decline. Based on their dominant position in German commercial and retail banking, savings banks and Land banks have defended their large market shares against private sector banks. This has arguably put German large private sector banks under more competitive pressure than their European peers, prompting them to retreat from this low-margin business. For a concise assessment of the current role of banks in the German financial system it might thus be misleading to follow the majority of international observers in their primary focus on private sector banks. Instead more attention should perhaps be devoted to the strong role of the savings banking and the co-operative banking group, as they seem to be more representative of the German banking system. As one telling piece of evidence, in an industry report on German banks analysts at JP Morgan view the large savings banks as sure candidates for the title of best bank in Germany (JP Morgan, 1999). Their strategic focus on

\footnotetext{
30 This decrease is only to a very small part due to the growing success of asset-backed-securities (ABS) transactions. According to a 1999-survey among twelve large private sector banks, approximately $3 \%$ of their total loans to German enterprises had been sold via ABS-transactions (Association of German Banks 2000, p. 17). Given that ABS-transactions are almost exclusively conducted by private sector banks, less than $1 \%$ of all outstanding bank loans had been moved off banks' balance sheets at the end of 1999.

31 Equity analysts highlight the lack of scale by comparing large commercial banks and large savings banks along ratios such as loans per branch and loans per employees. They find that average ratios are much lower for the private sector banks and make lower market shares responsible for this observation (Morgan Stanley Dean Witter, 2000, p.48)
} 
retail banking and relationship banking to SMEs, which ensure high market shares and cross selling opportunities, together with the ongoing trend for bundling common activities at both a macro and a micro level, which leads to considerable cost reductions, enable them to effectively respond to current challenges in their business environment. ${ }^{32}$ Viewed from this perspective and in the light of the trend by SMEs towards more bank financing, the German banking sector as a whole has apparently retained its importance for the German financial system and - in some specific areas - might even have become "more unique" compared to other capital market-oriented financial systems.

This uniqueness is underscored by the fact that there has hardly been any foreign influx into the German retail market during the last decades. As noted before, the combined market share in terms of total assets of subsidiaries of foreign banks and German banks owned by foreign institutions has remained constant at around 4\% since 1985. Moreover, according to a study in the year 2000 by the European Central Bank, almost 90\% of all 946 mergers and acquisitions in which German credit institutions had been involved between 1995 and 1999 were purely domestic in nature. A study in 2001 by the Bank for International Settlements (BIS) reports a similar home bias. It is based on a data set produced by Thomson Financial Securities Services that allows a distinction to be drawn between the origin of the target and the bidder bank. Between 1990 and 1999 the aggregated value of transactions in which a domestic bank was acquired by a foreign bank amounted to only $4 \%$ of the value of deals in which both target and bidder had been German banks. The German experts interviewed for the BIS study view the fact that savings and co-operative banks cannot be acquired by nongroup institutions as an important reason for the lack of cross-border M\&A activity.

Another possible reason for the small number of cross border transactions is highlighted in Hackethal (2001). He compares the strategy profiles of more than 600 European commercial banks and finds substantial differences between banks from different countries. Based on two sets of variables that attempt to capture each bank's market position and each bank's

\footnotetext{
32 La Porta et al (2002) have in a recent study analysed the role of public banks in 92 countries by measuring the government-owned portion in the ten largest banks per country in 1970 and in 1995, respectively. Due to the large size of Land banks, the figures for Germany are well above the average for both years. Their results which "[...] are consistent with the political view of government ownership of firms, including banks, according to which such ownership politicizes the resource allocation and reduces efficiency" (p. 290) imply that the savings bank group exploits market power at the expense of competitors and, ultimately, clients or, alternatively, that the relationship does not hold for Germany. In this paper, we argue in favour of the second explanation.
} 
endowment with resources he first clusters the sample banks into nine strategic groups. ${ }^{33}$ Logit models are then applied to identify those attributes that are best suited to discriminate between the banks in different strategic groups. He finds that banks in different groups differ more strongly with respect to market position than with respect to resource endowment. More importantly, he finds that one particular group is almost exclusively populated by German commercial banks. The average bank in that group stands out as one with a lower return, a lower variance in returns, a lower equity ratio, a smaller role of non-interest income and a comparatively high asset growth rate. Most British banks were found to belong to a second group while most French, Spanish and Italian banks all fell into a third category. Given that banks from the same strategic group can be assumed to be fairly homogenous with respect to their strategic profile but to differ substantially in that respect from banks in other groups, and based on the observation that the country of origin is particularly important in explaining group membership, it is conjectured that competition between similarly positioned domestic commercial banks is much more intense than competition between banks from different countries.

Moreover, Hackethal argues that strong path dependencies rooted in vast structural differences between European financial systems have caused $2^{\text {nd }}$ and $3^{\text {rd }}$ tier banks from different countries to react differently to identical changes in their business environment (e.g. regulatory harmonization and advances in technology) so that a convergence in terms of market-product combinations is not discernible. He concludes that these structural differences might at least partially explain the small number of instances in which foreign banks entered the German market. This line of reasoning implies that intensified competition from abroad is only to be expected if structural changes in the German banking market occur, i.e. if the dominant position of savings and co-operative banks erode.

\section{Outlook}

There are at least four major issues besides technological advances and financial and monetary integration that carry the potential for eroding the dominant position of public banks and thus for changing the German banking landscape as it has been described above.

\footnotetext{
33 The first set consists of variables such as growth rate in total assets, non-interest income over total income, loans to non-banks over assets and variance in returns; variables in the second include cost-income ratio, fixed assets over total assets, personnel expense per employee and non-bank deposits over total assets.
} 
German private sector banks have for many years argued that state guarantees have endowed public banks with higher credit ratings than they would merit on a stand-alone basis. As a consequence, Land banks and large savings banks would have benefited from lower refinancing costs which would have unduly skewed the level playing field in Germany. In July 2001, the European Commission decided that all forms of public guarantees are to be regarded as state aid under European Union law and are therefore illegal. As a result, the guarantee obligation must be fully abolished by 2005 and the maintenance obligation must be adjusted in such a way that the financial relationship between the public owner and the public bank does not differ from a relationship under private law, i.e. any subsidy must be reported to the Commission. There has been much speculation regarding the effect of such a ruling on the Land banks' competitive position. Based on the assessment that the ratings of Land banks would be lower on a stand alone basis than those of the big four commercial banks, some commentators reckon with a widening of the spreads of public banks' debentures by 25-50 basis points ${ }^{34}$. Others argue that only about one fifth of these securities are not backed by pools of collateral so that the total effect on absolute refinancing cost is much smaller. ${ }^{35}$ Because most funding of primary savings banks still comes from customer deposits that are fully secured by a deposit guarantee scheme, the removal of state guarantees will probably not have a big impact on their business model. The removal, however, may have an important side effect in terms of ownership and governance structures as it may serve as a catalyst for the privatization of savings banks. This would, in turn, surely pave the way for a consolidation across banking groups, since teaming up with savings banks is the only way for private sector banks to achieve greater scale in their retail business.

A second issue relates directly to the core deposits as the most important source of funding, which some analysts estimate to contribute almost $30 \%$ to the total net interest income of a savings bank. ${ }^{36}$ Should the trend of disintermediation on the banks' liability sides continue, savings banks will probably lose a competitive advantage that has traditionally helped them, inter alia, to offer better loan rates to their SME clients than private sector banks. Another factor that some observers believe to be responsible for the low margins in the corporate loan business is the alleged failure of many smaller German banks to stipulate prices that fully reflect the default risk of the debtor.

\footnotetext{
${ }^{34}$ See Donges et al (2001, p.17), Sinn (1996, p.45), and Morgan Stanley Dean Witter (2000, p.40).

35 See Menkhoff (1997, p.568).
} 
The new capital adequacy regulation as a third issue which might affect the future landscape in German banking will require banks to choose a level of regulatory capital that corresponds closely to the credit risks inherent in their loan portfolios. It might be argued that this puts smaller banks which do not possess a sophisticated internal rating and risk management system at a disadvantage. However, as network-affiliated lenders, all savings banks and also all co-operative banks are currently in the process of jointly setting up rating and risk management systems that shall be certified by regulatory authorities for the entire group of member banks and not for each single bank. Moreover, as new drafts of the proposed new regulation take into account the concerns of continental European governments and banks alike, the foreseeable effect of new capital requirements on the German banking structure is becoming less obvious (Schmidt 2001).

In conclusion, we do not believe that the non-private sector banks are about to lose their dominant position in the German (retail) commercial banking market in the short or medium term. It can be safely predicted that interest margins will further decrease due to an increasing price awareness of customers and an intensifying competition among all types of financial institutions. However, it seems equally safe to assume that both groups are in a position to react to increasing cost pressures by centralizing non-core functions and services and by conducting horizontal within-group mergers. Consequently, the opportunities to vertically disintegrate the industry value chain, which had been opened up by technological advances many years ago, will be finally seized by the banking industry, pushing back-office functions such as payment processing and custody outside the boundaries of many banks. It is even more likely that the consolidation trend in German banking will continue in the coming years. We will probably also witness an even stronger specialization of banks from different groups in terms of customers and products, i.e. public and co-operative banks will continue to successfully focus on retail and SME clients and larger commercial banks will focus on capital market-oriented business with corporations, larger SMEs, institutions and wealthy individuals.

\section{Conclusion}

In this paper we have argued that great care has to be taken when generalising structural trends from one financial system to another. Whilst conventional commercial banking is clearly in decline in the US, it is far from clear whether the dominance of banks in the

\footnotetext{
36 See JP Morgan (1999, p.10).
} 
German financial system has been significantly eroded. We interpret the immense stability in intermediation ratios and financing patterns of firms between 1970 and 2000 as strong evidence for our view that the way in which and the extent to which German banks fulfil the central functions for the financial system ${ }^{37}$ are still consistent with the overall logic of the financial system. Because of the observed stability and consistency we do not expect the German financial system and its banking industry as an integral part of this system to converge to the institutional arrangements typical for a market-oriented financial system.

However, in the light of recent developments in the German economy some words of caution are certainly warranted. In late 2002, record levels in insolvencies of German firms could be observed together with record levels of risk provisioning by German banks, historically low bank profitability levels, and massive layoffs of employees, especially in the area of corporate banking. The president of the German private banking association and chairman of Deutsche Bank's supervisory board, Rolf E. Breuer, declared that the state of the German banking industry has never been worse during the last 50 years. He expects that a third of all German banking branches will have to be closed soon. ${ }^{38}$

Many commentators argue that the dire business environment has finally uncovered a structural crisis in the banking industry that for many years was obscured by extraordinary effects: Reunification stimulated loan demand for much of the nineties and the booming equity markets in combination with the rise of the internet economy propped up the banks' fee business. Not only have these positive effects vanished but other costly effects such as the Year-2000- and the Euro-conversion as well as write-offs and follow-on costs of enormous internet technology investments have occurred in the recent past. It remains an open question whether the majority of German banks will eventually be able to cope with the growing challenges by concentrating on core competencies, improving efficiency and possibly by inter-group cooperation and consolidation, or whether the German banking industry is indeed in a state of terminal decline.

\footnotetext{
37 According to Bodie/Merton (1995) financial systems fulfil six basic functions, albeit by means of different institutional setups: 1) clearing and settlement of payments, 2) pooling of resources to undertake largescale indivisible enterprise projects, 3) transferring economic resources through time and across geographic regions and industries, 4) managing risk and uncertainty, 5) providing price information, 6) mitigating incentive problems.

38 Börsenzeitung, "Breuer erwartet Schließung jeder dritten Bankfiliale und weiteren Stellenabbau“, p.1, 13.12.2002.
} 


\section{References}

Allen, F./GALE, D. (1997): Financial Markets, Intermediaries and Intertemporal Smoothing, in: Journal of Political Economy, Vol. 105, 523-546

Allen, F./S ANTOMERO, A.M. (1997): What Do Financial Intermediaries Do?, Journal of Banking and Finance, Vol. 25, No. 2, 271-294

Association OF GeRman BAnKs (2000): Daten, Fakten, Argumente - Private Banken, Partner des Mittelstandes, Berlin, Mai

BeCKetTI, S./MorRIS, C.S. (1992): Are Bank Loans Still Special?, in: Federal Reserve Bank of Kansas Economic Review, Vol. 77, No.3, 71-84

MERTON, R.C./BODIE, Z. (1995): A conceptual framework for analyzing the financial environment, in D.B. Crane et al (eds.): The Global Financial System: A Functional Perspective. Harvard Business School Press, 3-31

BOYD, J.H./GERTLER, M. (1993): US Commercial Banking: Trends, Cycles, and Policy, in: O. Blanchard/S. Fischer (eds.): National Bureau of Economic Research Macroeconomics Review, 319-368

BOYD, J.H./GERTLER, M. (1995): Are Banks Dead? Or Are the Reports Greatly Exaggerated?, NBER Working Paper No. 5045

CALOMIRIS, C.W. (1997): On the Convergence of US Banks to International Norms in Corporate Banking, unpublished manuscript, $15^{\text {th }}$ International Seminar on the New Institutional Economics, Wallerfangen/Germany, June

CORBETT, J./JENKINSON, J. (1997): How is Investment Financed? A Study of Germany, Japan, the United Kingdom and the United States, in: The Manchester School Supplement, 69-93

DeRMine, J. (2002): European Banking: Past, Present and Future, Conference Paper for Second ECB Central Banking Conference on The Transformation of the European Financial System, Frankfurt am Main, 24-25 October 2002

DEUTSCHE BUNDESBANK (1995): Ergebnisse der gesamtwirtschaftlichen Finanzierungsrechnung für Deutschland 1990-1994, Special Statistical Publication No. 4, August

DEUTSCHE BundESBANK (1998): 50 Jahre Deutsche Mark, Monetäre Statistiken 1948-1997, CD-Rom, C.H. Beck, Vahlen

Deutsche Bundesbank (2000): Banking Statistics 2000, Statistical Supplement to the Monthly Report, November 2000

Deutsche BundesbanK (2001): Banking Statistics 2001, Statistical Supplement to the Monthly Report, March 2001

DeUTSCHE BundeSBANK (2001A): Die Ertragslage der deutschen Kreditinstitute im Jahr 2000, in: Monthly Report September 2001, 15-50

DEUTSCHE BUNDESBANK (2001B): Bankbilanzen, Bankenwettbewerb und geldpolitische Transmission, in: Monthly Report September 2001, 51-70

DEUTSCHE BUNDESBANK (2002): Zur Entwicklung der Bankkredite an den privaten Sektor, in: Monthly Report October 2001, 31-47 
DiAMOND, D. (1984): Financial Intermediation and Delegated Monitoring, in: Review of Economic Studies, Vol. 51, 393-414

Diamond, D./DybVig, P.H. (1983): Bank Runs, Deposit Insurance, and Liquidity, in: Journal of Political Economy, Vol. 91, 401-419

DONGES, J.B/EEKHOFF, J./MÖSCHE, W./NEuMANN, M./SIEVERT. O (20001): Privatisierung von Landesbanken und Sparkassen, in: Schriftenreihe Frankfurter Institut Stiftung Marktwirtschaft und Politik, Vol. 38

DSGV (2001): Markets 2000 (condensed annual report) - Business Development, Trends, Analyses

ECB (2000): Mergers and Acquisitions Involving the EU Banking Industry - Facts and Implications, Dec. 2000

ECB (2002): Report on Financial Structures, Frankfurt am Main

ENGLER, H./Essinger, J. (2000): The Future of Banking, London: Financial Times/Prentice Hall

EDWARDS, F.R. (1996): The New Finance - Regulation \& Financial Stability, Washington, D.C.: The AEI Press

EDWARDS, F.R./MISHKIN, F.S. (1995): The Decline of Traditional Banking: Implications for Financial Stability and Regulatory Policy, in: Economic Policy Review, Federal Reserve Bank of New York, Vol. 1, July, 27-45

FAHRHOLZ, B. (2001): Die Bank der Zukunft - Herausforderungen und Perspektiven, Lecture at Hohenheim University, June 20

FAMA, E. (1985): What's Different About Banks, in: Journal of Monetary Economics, Vol. 15, $29-40$

FREIXAS, X./ROchET, J.-C. (1997): Microeconomics of Banking, Cambridge, Mass.: MIT Press

Gorton, G.B./Rosen, R. (1995): Corporate Control, Portfolio Choice, and the Decline of Banking, in: Journal of Finance, Vol. 50, 1377-1420

GREENBAUM, S.I./THAKOR, A.V. (1995): Contemporary Financial Intermediation, Fort Worth et al.: The Dryden Press

HACKETHAL, A. (2001): How Unique are US Banks? - The Role of Banks in Five Major Financial Systems, Jahrbücher für Nationalökonomie und Statistik, Vol. 221, 592-619

HACKethal, A. (2001A): Strategic Groups in European Commercial Banking, GEABA Discussion Paper No. 01-19

HACKeTHAL, A./SCHMIDT, R.H. (2002): Financing Patterns - Measurement Concepts and Empirical Results (revised version), Working Paper Series: Finance \& Accounting, Goethe-University, Frankfurt a.M.

JAMES, C. (1987): Some Evidence on the Uniqueness of Bank Loans, in: Journal of Financial Economics, Vol. 19, 217-235

JP MORGAN (1999): German Banks - Sparkassen, Industry Update from Sept. 27 
KASHYAP, A.K./RAJAN, R.G./STEIN, J.C. (1999): Banks as Liquidity Providers: An Explanation for the Co-Existence of Lending and Deposit-Taking, unpublished manuscript, University of Chicago, NBER and MIT Sloan School of Management

LEADEM, S.R./ChAN, C.S./ENRICO, C./BRINKER, B./HEIDEGGER, H./OrLOPP, B. (2001): The Future of Corporate Banking in Europe, Joint Study by Goldman Sachs and McKinsey \& Company, Jan. 2001

LA Porta, R./LOPEZ-DE-SiLANES, F./ShleIFER, A. (2002): Government Ownership of Banks, in: Journal of Finance, Vol. 57, 265-301

LEWIS, M.K. (1991): Theory and Practice of the Banking Firm, in: C. Green/D.T. Llewellyn (eds.): Survey of Monetary Economics, Vol. 2, London: Blackwell Press

LiTAN, R.E./RAUCH, J. (1998): American Finance for the $21^{\text {st }}$ Century, Washington, D.C.: The Brookings Institution

Maestroeni, O. (2001), Pfandbrief-style products in Europe, in: BIS Papers No. 5: The changing shape of fixed income markets: a collection of studies by central bank economists, Basel, 44-66

MAYER, C. (1988): New Issues in Corporate Finance, in: European Economic Review, Vol. $32,1167-1188$

MENKHOFF, L. (1997): Öffentliche Banken - nutzlos und teuer?, in: Ifo-Studien 43, pp.549575

MILLER, G.P. (1998): On the Obsolescence of Commercial Banking, in: Journal of Institutional and Theoretical Economics, Vol. 154, 61-73

MORGAN STANLEY DEAN WiTTER (2000): German Banks, Jan. 19, 2000

MYERS, S.C./RAJAN, R.G. (1998): The Paradox of Liquidity, in: Quarterly Journal of Economics, Vol. 113, 733-771

OECD (1994): Bank Profitability 1982-1992, Paris

OECD (2000): Bank Profitability 1990-1999, Paris

RAJAN, R.G. (1996): Is there a Future in Banking? Towards a New Theory of the Commercial Bank, mimeo

RYBCZYNSKI, T. (1984): Industrial Financial Systems in Europe, US and Japan, in: Journal of Economic Behaviour and Organization, Vol. 5, 275-286

SCHMIDT, R.H. (2001): The Future of Banking in Europe, in: Financial Markets and Portfolio Management, Vol. 15 (No. 4), pp 429-449

SCHMIDT, R.H./HACKETHAL, A./TYRELl, M. (1999): Disintermediation and the Role of Banks in Europe: An International Comparison, in: Journal of Financial Intermediation, Vol. 8, 36-67

SCHMidT, R.H./HACKethal, A./TyRELl, M.(2002): The Convergence of Financial Systems in Europe, in: Schmalenbach Business Review, Special Issue 1/02, 7-53

SinN, H.-W.(1996): Der Staat im Bankwesen - zur Rolle der Landesbanken in Deutschland, München

White, W.R. (1998): The Coming Transformation of European Banking?, BIS Working Paper No. 54 
Appendix: The 30 largest German banks by asset size (end 2000)

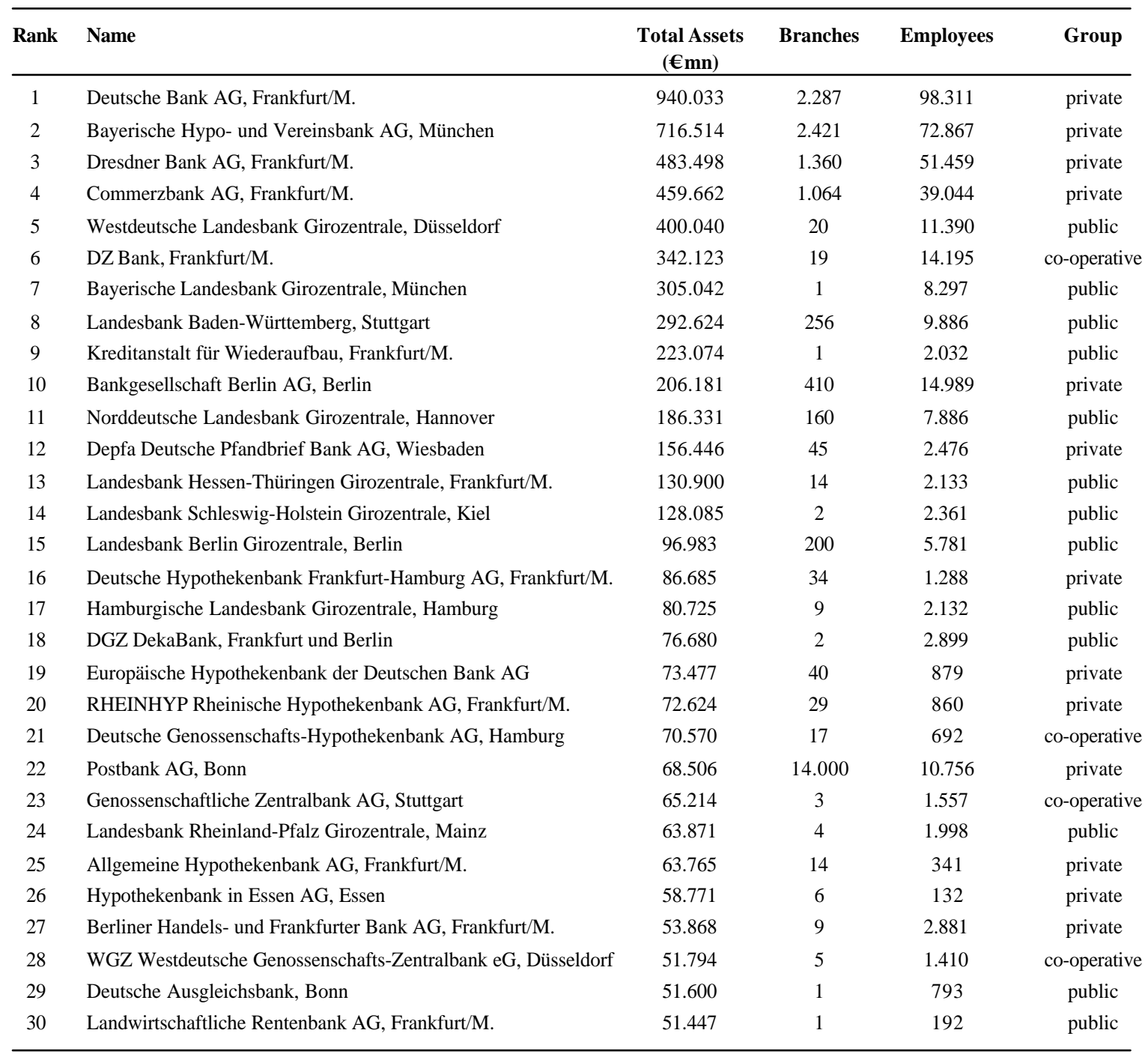

Source: Website of the German Banking Association (www.bdb.de) 


\section{CFS Working Paper Series:}

\begin{tabular}{ll} 
No. & Author(s) \\
\hline $2003 / 17$ & Erik Theissen \\
& \\
$2003 / 18$ & Roman Kräussl
\end{tabular}

Title

Organized Equity Markets in Germany

2003/19 Karl-Hermann Fischer Christian Pfeil

Do Credit Rating Agencies Add to the Dynamics of Emerging Market Crises?

Regulation and Competition in German Banking: An Assessment

2003/20 Ralf Elsas

Jan Pieter Krahnen

Universal Banks and Relationships with Firms

2003/21 Günter Gebhardt

Rolf Reichardt

Carsten Wittenbrink

2003/22 Roman Kräussl

Do Changes in Sovereign Credit Ratings Contribute to Financial Contagion in Emerging Market Crises?

2003/23 Roman Kräussl

A Critique on the Proposed Use of External Sovereign Credit Ratings in Basel II

2003/24 Tereza Tykvová

Is the Behavior of German Venture Capitalists

Different? Evidence from the Neuer Markt

2003/25 Tereza Tykvová

The Role of the Value Added by the Venture

Capitalists in Timing and Extent of IPOs

2003/26 Stefanie Franzke

Initial Public Offerings and Venture Capital in

Stefanie Grohs

Germany

Christian Laux

2003/27 Andreas Hackethal

German banks - a declining industry?

Copies of working papers are available at the Center for Financial Studies or can be downloaded (http://www.ifk-cfs.de). 